\title{
Motivation for Air-Launch: Past, Present, and Future
}

\author{
John W. Kelly,* Charles E. Rogers, $\uparrow$ Gregory T. Brierly, $\$$ J. Campbell Martin, $§$ and Marshall G. Murphy** \\ NASA Armstrong Flight Research Center, Edwards, California, 93523
}

\begin{abstract}
"Air-launch" is defined as two or more air-vehicles joined and working together, that eventually separate in flight, and that have a combined performance greater than the sum of the individual parts. The use of the air-launch concept has taken many forms across civil, commercial, and military contexts throughout the history of aviation. Air-launch techniques have been applied for entertainment, movement of materiel and personnel, efficient execution of aeronautical research, increasing aircraft range, and enabling flexible and efficient launch of space vehicles. For each air-launch application identified in this paper, the motivation for that application is discussed.
\end{abstract}

\section{Nomenclature}

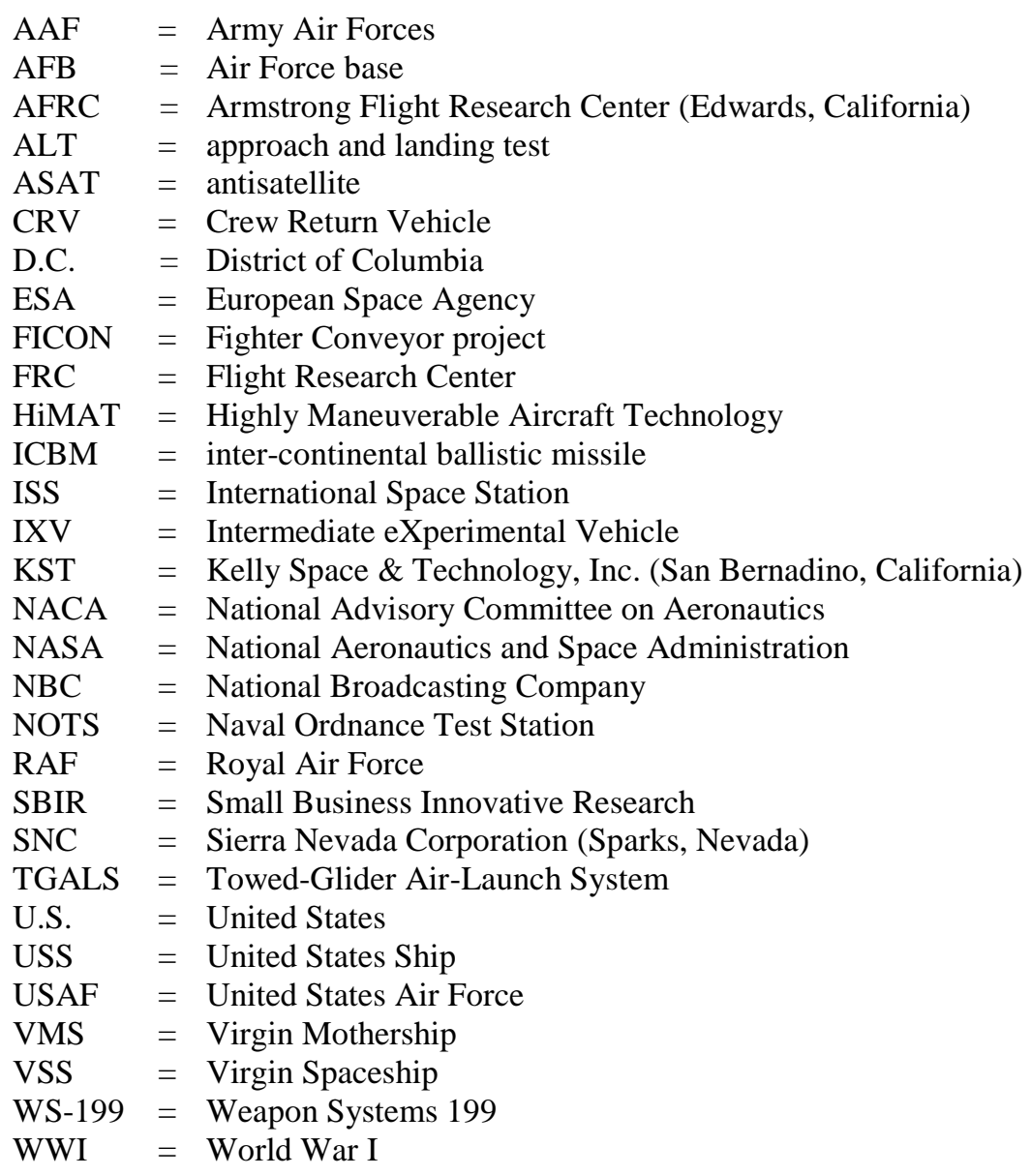

\footnotetext{
* Project Manager, Exploration \& Space Technology Directorate, Senior Member.

$\dagger$ Project Manager, Exploration \& Space Technology Directorate, Senior Member.

† Chief Information Officer, Mission Support Directorate, Member.

$\S$ Office of External Affairs and Government Liason, Associate Fellow.

** Intern, Office of Strategic Communications, Student Member.
} 
WWII = Word War II

\section{Introduction}

$\mathrm{T}$

HIS paper examines the motivation for and application of air-launch as a means of solving aeronautical and aerospace problems in military, civil, and commercial contexts throughout history and into the future. For the purposes of this paper, "air-launch" is defined as two or more air-vehicles joined and working together, that eventually separate in flight, and that have a combined performance greater than the sum of the individual parts. The definition of "air-vehicles" includes, but is not limited to: airplanes (powered and unpowered), airships, blimps, balloons, space launch vehicles, and munitions, so long as those munitions are integrated into a guided air-vehicle. This definition of air-launch specifically excludes release of unguided munitions (i.e., dumb bombs dropped from an aircraft).

\section{Early Air-Launch}

From the very beginning of heavier-than-air flight, air-launch has been envisioned as a means of enhancing the performance of an air-vehicle. In 1892, the United States (U.S.) Patent Office, responding to Louis Mouillard's patent application for a rigid-wing glider, explains: "Examining the project presented we believe that the described invention as a whole is not practical, since the machine cannot rise without a balloon" [1]. The patent office was not convinced that a glider, by itself, could take flight. A glider needed another air-vehicle to join with it to enhance its performance.

The use of a balloon as a means of gaining potential energy for subsequent flight of a glider was not such an absurd idea. In fact, on more than one occasion in 1905, John Montgomery launched his tandem-wing Santa Clara glider from a hot air balloon as spectators looked on [2] [p. 5]. Besides being a public demonstration of controlled flight of a heavier-than-air craft, which was still a novelty at the turn of the twentieth century, these flights were also a bit of a parlor trick. In Montgomery's own words:

I had a few carping critics that I silenced by this standing offer: If they would deposit a thousand dollars, I would cover it on this proposition. I would fasten a 150-lb sack of sand in the rider's seat, make the necessary adjustments, and send up an aeroplane, upside down with a balloon, the aeroplane to be liberated by a time fuse. If the aeroplane did not immediately right itself, make a flight and come safely to the ground, the money was theirs. [3]

In July of that year, a final flight of the Santa Clara air-launch demonstration was made and Montgomery clearly states the intention, "The ascension was given to entertain a military company in which were many of [the pilot's] friends and he had told them he would give the most sensational flight they ever heard of" [3]. Give them the most sensational flight he did. Unbeknownst to the pilot, a guy line from the balloon had fouled the Santa Clara, and upon release from the balloon the glider plummeted uncontrolled to the earth, killing the pilot. After the accident, Montgomery ceased these balloon-launched glider demonstrations.

\section{Lighter-Than-Air Air-Launch}

By 1914, not yet a decade after the air-launched flights of the Santa Clara, the world was at war. At this time, many nations were producing both lighter-than-air and heavier-than-air aircraft for military use. Indeed, aircraft played a significant role in the Great War.

In the North Sea, the British Royal Navy imposed a blockade that limited materiel and foodstuffs from entering or leaving German ports. To counter the blockade, above the German Bight, ${ }^{1}$ zeppelins were used for scouting enemy mines and warships, and for protecting German minesweepers and submarines. These airships proceeded largely unhindered for the first three years of the war, as they were able to detect opposing surface vessels at a sufficient distance to allow for evasive maneuvers. Additionally, there was no threat from the air, as there were no British aircraft with the range to reach the Bight, engage the enemy airship, then subsequently return to England [4] [p. 234].

This situation changed in 1917 as the British Navy devised ways to engage the zeppelins. In April and May, the Royal Naval Air Service took delivery of four Curtiss Model-H.12 "Large America" flying boats. This new weapon had the endurance to make the round trip from England and had the armaments to extirpate the floating sentry. On May 14, 1917, H.12 No. 8666 destroyed zeppelin L 22. Exactly one month later, H.12 No. 8677 destroyed zeppelin L 43 [4].

\footnotetext{
${ }^{1}$ The southeastern [corner] of the North Sea bounded by the Netherlands and Germany to the south, and Denmark and Germany to the east; https://en.wikipedia.org/wiki/German_Bight [retrieved 10 July 2017].
} 
In July that year, the Royal Navy had also re-launched several light cruisers fitted with a fly-off foredeck and five Sopwith Pups. Although ultimately effective against the zeppelin, this configuration was not ideal, as the Pup could not land aboard, nor did it have the endurance to reach England should it be launched from the cruiser while in the Bight. The only option was for the pilot to ditch the Pup at sea, then await his rescue by a surface vessel. On August 21, 1917, a Pup launched in this way from HMS Yarmouth destroyed zeppelin L 23 [4] [pp. 243, 244].

With this new airborne threat, zeppelins had only two effective defenses: 1) fly near German bases where fighter-escorts could protect them; or 2) fly far above the useful altitude of the attacking aircraft. For patrols beyond the help of fighter-escort, the Imperial Navy ordered the zeppelins to fly at an altitude of 4000 meters, or approximately 13,000 feet [4] [p. 241]. At this altitude, the scouting ability of the zeppelins was rendered ineffective. An alternate defense was required. Robinson describes a newly devised defense for the zeppelin and the unique air-launch test that follows:

Officers of the Aviation Department of the German Admiralty in Berlin envisaged another type of defence - a fighter plane hung under the airship which might be released in the event of an attack. A standard German navy Albatros D-III fighter was delivered to the Airship Experimental Command in Jüterbog, and hung up under $L 35$... On January 25, 1918, L 35 carried the Albatros aloft, but it was not dropped. Next day the plane was released at 4,600 feet, and after diving about 150 feet, it picked up speed and flew away. [4] [p. 246]

Although the air-launch test was successful, German Admiralty chose not to pursue this capability as a defense for the zeppelins.

By June 1918, the capability of launching a "parasite fighter" from an airship was also being tested by the British Navy. A Sopwith Camel was suspended from a "little crook anchoring gear" under airship R23. The testing culminated on November 6 when $R 23$ air-launched the Camel which subsequently landed successfully [5]. The U.S. Navy performed a similar air-launch experiment in 1918 when "a few weeks after the Armistice the experiment was tried successfully at Fort Tilden, New York, using the Navy blimp $C$-1 and an Army JN4 [sic.] airplane" [6] [p. 19].

Other than these very limited tests, serious consideration of joining an airplane to an airship was not made until the development of the USS Akron and the USS Macon, rigid airships of the U.S. Navy. The capability to carry fighter aircraft for defense was included in the design specification for these airships. However, very little testing of the airship-airplane combination had been performed to this point in time, but would be required for an operational system. The systems and operational doctrine for the Akron-class rigid airships would be worked out through a series of tests years before Akron and Macon were commissioned.

The first of such tests that contributed, but was not directly related to the development of the Akron-class rigid airships, occurred in late-1924 when the U.S. Army Air Service conducted air-launch and hook-on tests between a Sperry "Messenger" aircraft and non-rigid blimps. The Messenger was equipped with a hook above the top wing of the bi-plane; the blimps were equipped with a rigid "trapeze" secured to the bomb racks below the envelope. The first test was conducted between the dates of October 2-4, 1924. Blimp TC-5 carried the Messenger aloft and released it from an altitude of 1500 feet above the ground [7] [p.101]. Subsequently, on December 14, 1924, the Messenger made the first successful hook-on landing to blimp TC-3 and subsequent air-launch release [7] [p.98]. Through these tests with the Messenger and Army blimps, a flying technique was established for hook-on and unhook (air-launch) maneuvers.

In the subsequent years, the U.S. Navy adopted this trapeze technique and continued developing it with an eye toward the Akron-class airship. The Navy utilized USS Los Angeles experimental rigid airship for the work at U.S. Naval Air Station, Lakehurst, New Jersey. The trapeze was installed on Los Angeles in December 1928, but flying work did not get underway until summer of 1929 [6] [p .21].

Parasite aircraft flight testing with Los Angeles began on July 3, 1929, and ended late-October, 1931, just before she was decommissioned in January 1932. Over the course of the flight-test program, several airplane types were used for hook-on and release (air-launch) testing. The Vought UO-1 was the first airplane utilized and was used until the Station acquired six surplus Consolidated N2Y-1s, which were delivered in March 1931 and first utilized for flight testing in June of that year. Nighttime hook-on testing was conducted with the N2Y in September 1931 [6] [pp. 19-30].

The Navy had chosen the Ryan F9C fighter for operational use on the Akron-class airships. The Station took delivery of the first XF9C-1 fighter in mid-October, 1931, and conducted its first hook-on tests with this airplane on October 23, 1931, just three months before the decommissioning of Los Angeles. When USS Akron and USS Macon finally came on line (October 27, 1931, and June 23, 1933, respectively) [6] [p. 180], each airship hangar bay was fitted with four F9C fighters which were an integral part of airship flight operations.

While she was active, another airplane type flew from Los Angeles, a motorless glider. Admiral Moffett was interested in the potential of using a glider to transport a mooring officer from the airship to the ground. On January 31, 1930, a Prüfling glider, fitted to a special attachment on Los Angeles, was lifted into the air, launched, 
then made a successful landing some 13 minutes later. The glider flew only one more time on Memorial Day, 1930, before a crowd of 15,000 spectators at the Curtiss Marine Air Race in Washington, D.C. Although these flights demonstrated that air-launch of a glider from an airship was viable, its value as a means of landing a mooring officer was questionable, and the flights did not continue [6] [p. 25].

Throughout the 1930s, airships struggled to maintain relevance in the U.S. Navy [6] [p. 147]. So, there was political value in flying the airship in the presence of the public and in front of those in positions of influence. The hulk of an airship flying overhead is impressive enough, but the sight is even more potent with the daring of an aerial trapeze act. On more than one occasion, Los Angeles performed her act before a crowd. On August 28, 1929, she gave her first public demonstration before a crowd of 100,000 at the National Air Races in Cleveland, Ohio [6] [p. 23]. On May 20, 1930, she performed her act before President Hoover, who was aboard the cruiser Salt Lake City off the Virginia Capes performing a Presidential review of the Fleet. Capitalizing on the event, the Naval Air Station allowed a National Broadcasting Company (NBC) announcer aboard Los Angeles who gave the background and a play-by-play of the trapeze act to his radio audience [6] [p. 25]. As mentioned earlier, Los Angeles also performed the act before a crowd of 15,000 at the Curtiss Marine Air Races on Memorial Day 1930.

Crowd-pleasing aside, the overarching motivation for the trapeze act was a military one. As with the zeppelin in World War I (WWI), the rationale for joining an airplane to an airship was that the fighter airplane would provide protection for the airship scout. However, as the development of this airship-airplane system evolved, that rationale shifted. It was apparent to some in the Navy testing program that the airship was useful as a high-speed, "lighterthan-air carrier." In other words, rather than the airplane providing a defense for the airship-scout, the airship could be the means of transporting the airplane-scout. By 1934, the "lighter-than-air carrier" rationale had won out, but by then it was too late. USS Akron had already crashed in April 1933, killing chief airship advocate Admiral Moffett [6] [pp. 77-92]. Then in February 1935 off the California coast, USS Macon-the single remaining rigid airship of the U.S. Navy - suffered a structural failure and was also lost at sea [6] [pp. 147-162]. Lost with her were the hopes of a "lighter-than-air carrier." The Macon was the last rigid airship of the U.S. Military, and with her loss, the era of lighter-than-air air-launch came to an end.

Or did it? In recent news, ${ }^{2}$ Amazon.com has made patent application ${ }^{3}$ for an "aerial fulfillment center" that has components and techniques not unlike the composite airship-airplane systems of the early 20th century. In the patent, Amazon.com envisions a large lighter-than-air flying warehouse that air-launches small UAVs to deliver products to its customers. Given the recent success of Amazon.com, highlighted by the recent success of its sister company Blue Origin, flying the reusable suborbital New Shepard system to space and back, ${ }^{4}$ there is a real possibility that we have not seen the last of lighter-than-air air-launch.

\section{Aero-Tow Air-Launch}

Aero-tow is a technique where one aircraft pulls another trailing aircraft horizontally by means of a tether or a stiff connection. This aero-tow method can be likened to a truck pulling a trailer, with a distinct advantage in the amount of mass that can be carried. The excess thrust of the tow airplane can be used to pull another airplane (usually unpowered) that is lifting its own weight plus the weight of its cargo. Vehicles that are aero-towed and subsequently released fit the definition of air-launch in this paper and have had a significant role in the history of aviation. The first successful aero-tow occurred in 1922 in the U.S. The aero-tow method was soon after adopted around the world, most notably for use within the sport of sailplanes, but also in war and in aerodynamic research.

\section{A. The First Aero-Tow}

In October 1922 on Manhasset Bay, Long Island, New York, Glenn Curtiss, proprietor of the Curtiss Airplane \& Motor Company, demonstrated aero-tow for the first time. For the demonstration, a Curtiss Flying Boat was used to pull a newly developed flying-boat glider. The Curtiss Flying Boat towed the glider behind it using an 800 -foot long towline. Short gives an account of this first flight:

After a short run, the glider lifted off the water surface first and the tow plane rose next. Both aircraft gained altitude quickly and flew over the entire length of Manhasset Bay, the tow plane about 175 feet and the sailplane 200 feet in the air. Reaching the opposite side of the shore, the glider released and glided easily down to the surface of the water, landing with a small splash, which did not even spray the pilot. [8] [p. 10]

Curtiss undertook the aero-tow demonstration because he felt that "sail planes," as the Germans had called them, had distinct advantages in efficiency. "By lessening our speed and increasing our load we cheapen air transportation

\footnotetext{
${ }^{2}$ https://www.theverge.com/2016/12/29/14114190/amazon-patent-drone-airship-delivery [retrieved 21 June 2017]

${ }^{3}$ United States Patent 9,305,280

${ }^{4}$ http://spacenews.com/blue-origin-flies-new-shepard-on-suborbital-test-flight/ [retrieved 21 June 2017]
} 
and make it more generally available" [9]. Curtiss, enamored by the flight of soaring birds, felt that men, too, could take advantage of efficient, motorless flight. "Out of gliding and soaring flight we can learn how to build lighter, more efficient airplanes, and, having built them, to utilize natural air currents to the consequent saving of artificial motive power" [9].

Others who witnessed the aero-tow demonstration had different ideas. "General Patrick and Rear Admiral Moffett, representing the army and navy, watched the flights with a view to a military application. They agreed that the glider could be developed as a moving, unmanned aerial target long sought by aviation officers" [8] [p. 10]. Others envisioned "aerial trains" [8] [p. 9].

\section{B. Military Gliders}

Meanwhile, in post WWI Germany, the Germans were developing their own ideas for the use of aero-towed gliders. The Treaty of Versailles had prohibited the production and import of aircraft of all kinds in and into Germany [10] [p. 204], and prohibited Germany from reestablishing an air force. Germany took advantage of this situation to excel in soaring. Glenn Curtiss expresses his admiration for the Germans' advancements, "The astounding success of the German [pilot] Heutzen in remaining aloft in a motorless airplane for two hours and ten seconds opens the door to a new phase in aeronautical development" [9]. Curtiss presciently adds:

This achievement may be regarded as a direct result of the restrictions in aviation imposed on Germany by the terms of the Versailles treaty. Necessity is ever the mother of invention, and when the vanquished were told by the victors that aerial experimentation could be carried on only with low-powered aircraft the inevitable impetus was given to gliding and soaring flight. [9]

Besides advancements in recreational soaring, the Germans also began to secretly develop a military capability of powered and unpowered aircraft. By 1936, Germany had a formidable air force that they put on display in the battlefield of the Spanish Civil War. By 1940, it had augmented that battle-hardened force with military gliders, which it used to great effect during World War II (WWII). Mrazek contends that the Germans were the first to use gliders as an instrument of war and gets at their motivation:

The Germans were most likely first ... in conceiving of the glider as an opportunity to develop new and unorthodox means of waging warfare. This concept was either Udet's ${ }^{5}$ or Student's. ${ }^{6}$ Udet thought of the glider as the modern equivalent of the Trojan Horse, landing soldiers in stealth and silence behind enemy lines. Student's approach was more aggressive. He saw gliders as a direct attacking and fighting weapon. He was to see his theory vindicated when Hitler ordered him to capture the Belgian fort, Eben Emael, in the opening attack on the West in May 1940. Eleven gliders carrying seventy-eight glidermen landed on the world's most "impregnable" fort and neutralized its 780-man garrison within twenty minutes. The next day, the fort capitulated. With this feat, glider warfare was born. [11] [p. 285]

In addition to being a weapon used for assault, the glider had many other uses and advantages. Mrazek explains: What advantages did gliders have that made them a useful weapon in combat and a desirable cargo carrier? There were many. Gliders gave mobility to ground units. Using gliders, forces could leap rivers, mountains and enemy defenses to make vertical envelopment possible. Field armies could operate in a third dimension. Gliders made airborne warfare not only a possibility, but also a reality. Gliders could carry a squad, a platoon or a company in a single load. They discharged units ready to fight, not scattered over a landscape in the way paratroopers landed.

Gliders were also cheap to manufacture, in contrast to the cost of a powered aircraft. According to the number of gliders an aircraft towed, they could double or triple the amount of men or cargo a single aircraft could move through the air. Most important of all, the glider was silent. Stealth was its trademark, and the terror it spread was a psychological advantage of unsurpassed importance. [11] [p. 281-282]

The German success at Eben Emael provided the impetus for other nations to adopt the use of gliders for their forces. In June 1940, one month after the German victory, British Prime Minister Winston Churchill ordered "the creation of a 5000-man parachute force - with a proportionate glider element-by the spring of 1941" [11] [p. 24].

In 1937, during the Sino-Japanese war, the Japanese had developed three transport glider types for testing. However, the Japanese transport glider development picked up in earnest in June 1940 after news about the German victory at Eben Emael reached Japan [11] [p. 344].

Mrazek intimates that the U.S. glider program was also initiated because of the same, "In February 1941, the U.S. Army Air Corps found that in 'view of certain news from abroad' that a study should be initiated on developing a glider that could be towed by aircraft" [11] [p. 360]. The U.S. took seriously the business of wartime gliders, producing 2-to-1 the number of all other countries combined by the end of the war.

\footnotetext{
${ }^{5}$ General Ernst Udet was a German World War I fighter ace and was involved in the German glider research and development program from its inception.

${ }^{6}$ General Kurt Student headed the German airborne forces during WWII.
} 
The only other nation with an appreciable glider force was the Soviet Union, who had developed a transport fleet of 400 A-7 gliders in 1939, before the German victory at Eben Emael. It is possible that the Soviet glider program was the inspiration to German military leaders. The Soviets had revealed their GN-4 glider to the public in 1934. The GN-4 was the world's first transport glider and "stood between the sailplane and the wartime transport glider" [11] [loc. 427]. Both General Udet and Hauptmann Student had visited the Soviet Union many times prior to the start of WWII [11] [loc. 284].

By the end of the war, gliders had been used for transportation of troops and materiel in nearly every major campaign. The primary combatants in the war had produced several thousand gliders. Table 1 is a summary of the combatant nations and an approximate number of gliders produced for the war effort. Note that, there were several other nations that had developed and utilized gliders during the war, but not in any appreciable numbers.

Table 1. Military Gliders Produced in WWII.

\begin{tabular}{|l|l|}
\hline \hline Nation & Approximate Number Produced during WWII \\
\hline Germany & 4000 \\
\hline Britain & 2200, plus 740 CG-4s imported from the U.S. \\
\hline Japan & 800 \\
\hline Soviet Union & 400 \\
\hline United States & 16,000 \\
\hline \hline
\end{tabular}

The size and capabilities of the nations' gliders were quite varied. Some were used for assault, many were used for transport of troops and materiel. Some carried a squad, while others could carry dozens of fully equipped troops. Some carried small motorized vehicles or field artillery, while others were designed to deliver a tank to the battlefield. The only limit as to the amount of men or materiel that could be delivered was the capability of the tow airplane.

\section{Me-163 Aero-Tow}

While the world's forces were aero-towing troops and materiel to the battlefield, the Germans were using aerotow for another purpose. The Messerschmitt Me-163 aircraft was a rocket-powered interceptor that was operationally deployed during World War II. As normally operated, the Me-163 interceptor performed a ground take-off using a jettisonable two-wheel dolly, climbed to its operational altitude using its liquid rocket engine, attacked Allied bombers and fighters, and then would glide to a landing on a central retractable skid. While the Me-163B variant was capable of a maximum speed of $596 \mathrm{mph}$ from a ground take-off, the earlier Me-163A was limited by its oxidizer and fuel capacity to a maximum speed from a ground take-off of $570 \mathrm{mph}$. An Me-163A prototype, the Me-163A V4 variant, reached $623.85 \mathrm{mph}$ (Mach 0.84) by being towed to altitude by a Messerschmitt Bf110C heavy fighter to conserve the oxidizer and fuel that would normally be used for the climb to altitude, and was then released from the tow-plane with a full load of fuel for the maximum speed test flight [12].

Me-163A prototypes, and the prior DFS-346 prototypes of the Me-163 aircraft design, had already been towed to altitude for glide testing prior to the installation of liquid rocket engines, so towing a fully-fueled Me-163A aircraft to altitude for increased performance was a natural extension of this technique. In this case, towing to altitude for air-launch allowed the aircraft to be glide-tested before installing the liquid rocket engine, and for powered flights allowed an increase in performance by saving the fuel that would normally be used for the climb to altitude [12].

\section{Peculiar Glider and Aero-Tow Air-Launch Configurations}

A few peculiar configurations that were developed during WWII are worth a mention. After WWII, aero-tow for space-launch has also been considered.

\section{Mistelschlepp}

Although not an aero-tow method, Mistelschlepp is a technique developed by the Germans where the "tow" airplane is rigidly attached to the top of the glider. The combined two-ship stack used the motive force of the fighter for take-off. Once the fighter released the glider from beneath it, it loitered overhead to provide protection. This method was used by the Germans many times during the war [11] [p. 317].

\section{Starrschlepp}

Starrschlepp is a technique that utilized a rigid connection between tow and towed airplanes in place of the usual tether. This method was borne out of tests to demonstrate the use of a glider as a flying fuel tank to extend the range 
of the towing bomber. There were distinct advantages to a rigid connection, most notably reduced fatigue on the flight crew of the glider, which was especially true for tow at night. The Germans relied upon this tow technique toward the end of the war when night flying was essential to avoid detection. The most significant disadvantage with the technique was that the tow-plane required relatively significant modifications, and therefore time, to accommodate the rigid connection. The Germans could not afford for their bombers to be out of action for any length of time. As a result, this system was not used as much as tethered tow [11] [p. 318].

\section{Multiple Glider Tow}

In September 1943, the U.S. Army Air Corp tested the tow of two gliders behind a tow aircraft. Towing more than one glider behind the tow aircraft had the distinct advantage of concentrating troops or materiel delivered, as well as reducing the airspace required for the delivery. After this technique was developed, it was commonplace for a Douglas C-47 Skytrain to tow two gliders [11] [p. 417].

\section{Aero-Tow for Space Launch}

Aero-tow has also been considered as a means of carrying launch vehicles that deliver payloads to space. There are two systems in particular that are addressed in the section, Air-Launch for Space Access: Eclipse and TowedGlider Air-Launch System.

\section{Parasite Bombs}

Air-launch played a prominent role in the development of precision-guided munitions. Early in the $20^{\text {th }}$ century, engineers recognized that bombs and torpedoes could use controlled flight to more accurately reach targets.

\section{A. The Impetus to Air-Launch}

A primitive execution of this development was the Curtiss-Sperry Aerial Torpedo, first successfully flown in 1918 [13]. The "torpedo" was an unmanned biplane that could take off, fly a path, drop a bomb, and then land in water to be recovered and reused. This biplane could be controlled via radio signal or internal guidance gear that would direct the airplane to its target. The airplane tests largely were failures. In only one test did the airplane successfully fly, drop its ordinance, and land for recovery [13]. However, the Aerial Torpedo foreshadowed the rise of guided munitions and of unmanned aerial vehicles in general.

A drawback of systems like the Curtiss-Sperry was their requirement for ground takeoff. These systems required almost everything a normal airplane needed, yet were disposable or, at best, very likely to be lost in flight. The next phase in guided munitions development would leverage air-launch to minimize cost and complexity while still better ensuring that bombs and torpedoes reached their targets.

World War II spurred guided munitions development at an unprecedented rate, perhaps chiefly with the idea of the "flying bomb." More insightfully categorized as early cruise missiles, flying bombs were explosive-laden aerial vehicles that could follow a specific flight path to plow into enemy targets near and far. Flying bombs needed wings, control surfaces, guidance, and in some cases, engines to reach their targets, but they did not need landing gear. After all, they were not meant to survive their flights. It made sense to launch these gear-less flying bombs from carrier aircraft. In addition, air-launch gave flying bombs speed and altitude boosts, effectively extending their range.

\section{B. German Flying Bombs}

In 1942, Germany launched the first V-1 flying bomb, a landmark in the history of guided munitions [14]. The V-1 flying bomb was a pulsejet-powered, winged bomb capable of flying its 1832-lb warhead to targets up to 250 miles away. Though the majority of V-1 flying bombs ground-launched via ramp, some later versions airlaunched from Heinkel He.111 H-22 bombers, which extended the bomb range [15]. The V-1 flying bomb managed to fly from France to the United Kingdom, all without directly risking German pilots [15].

Meanwhile, Germany also introduced the Ruhrstahl/Kramer X-1, or Fritz X, a pioneering radio-guided bomb [16]. The Fritz $X$ was released from a bomber and human-guided via radio signal to its target. The bomb featured moveable aero-surfaces, which essentially classified it as a glide bomb. The Fritz X production line was glacially slow, and the requirement for bomber crews to remain vulnerably over the target area in order to guide the bomb caused unusually high losses of its carrier aircraft [16]. Ultimately, the Fritz X, despite its innovative design, was insufficient to reverse the course of the war. 
The Henschel Hs 293, like the Fritz X, was a German radio-guided anti-shipping bomb [16]. Also, like the Fritz $\mathrm{X}$, it proved cumbersome. The bomb required pilots to fly a straight, level course in order to use the bomb successfully, exposing its carrier aircraft to anti-aircraft fire.

As the war progressed in favor of the Allies and as desperation increased within Axis ranks, German designers modified the V-1 design into the manned Fi 103 Reichenberg [15]. The Fi 103 airplane was designed to be airlaunched from an He.111 bomber and piloted to its target, with the pilot, in theory, egressing the airplane and parachuting to safety moments before impact. Though test flown by famed German aviator Hanna Reitsch (among other pilots), production of the Fi 103 airplane was cancelled before it entered combat.

Germany eventually lost WWII, but the V-1 flying bomb innovations were not lost with it; the United States duplicated captured V-1 flying bombs as Republic-Ford JB-2s and tested them via air-launch beginning in 1944 [17].

Echoing the desperate design of the Fi-103 airplane was the Mistel, an unmanned, explosive-filled Junkers Ju-88 bomber guided aloft by a piloted Focke-Wulf Fw 190 fighter and released at altitude to dive into a ground target [18]. Both aircraft in the Mistel system were heavily modified. The expendable bomber was stripped of all interior fittings and packed with extra fuel; the fighter cockpit was modified so its pilot could control the bomber. The Mistel first saw combat in 1944, but had negligible effect and faded quietly with the end of the war [18].

\section{Japanese Ohka}

As Germany collapsed, their allies in the Empire of Japan began widespread deployment of suicide aircraft. Although Japanese Kamikaze pilots perhaps are best known for crashing repurposed fighters and bombers into allied targets, the Japanese also deployed purpose-built suicide aircraft, the Yokosuka MXY7 Ohka. The rocket-powered Ohka was designed to drop from a Mitsubishi G4M "Betty" bomber and race along with its 2645-pound onboard bomb toward an explosive end at its target [19]. By using air-launch, the Ohka systems could be minimized to only what it needed for flight and detonation. Further, air-launch allowed the Ohka to take advantage of short-range rocket propulsion, providing it with a quick boost of exceptional speed. Although the Ohka garnered a small amount of combat validation after its March 1945 debut, ${ }^{7}$ its Betty carrier aircraft were vulnerable to allied airplanes due to shortages of fighter escorts [19, 20]. Like the German Fi-103 flying bomb and Mistel concepts, the Ohka was a lastditch concept that failed to alter the war. Nonetheless, the Ohka, like the V-1 and Fi-103 flying bombs, hinted at the advantages air-launched guided missiles.

\section{U.S. Flying Bombs}

The allied forces, particularly the United States, also developed vast improvements in guided munitions technology throughout WWII and used air-launch to enable that development.

The U.S. Army Air Forces (AAF) tested air-launched bomb gliders, also known as "glombs," throughout the war. In 1942, the AAF first tested the Fletcher XBG-1 bomb glider [11] [p. 415]. The XBG-1 was a glomb airlaunched from a bomber and radio-guided to its target. It was never fielded to combat. The GB-4 and GB-8 glombs featured television inputs for their radio control systems, and the GB-4 glomb even reached combat [21]. Though the glombs were mostly ineffective on the battlefield, they further advanced the concept that air-launch could provide guided munitions with larger ranges, simpler designs, and thus, better overall effectiveness.

The U.S. Navy, meanwhile, developed the ASM-N-2 Bat. The Bat was a radar-homing, anti-shipping glide bomb launched from a PB4Y-2 Privateer bomber. The missile, which could guide itself to targets up to 20 miles away without any post-launch input from pilots, was revolutionary for its time [22]. Air-launch, as with other flying bombs, allowed the Bat design to focus on flying, aiming, and destroying; all with a boost in altitude and speed it would not have received if launched from a ship or shore. The Bat was first utilized in April 1945, when it damaged two Japanese freighters [22]. It tallied further successes against Japanese shipping throughout the final months of WWII [23]. The Bat stands as a pioneering guided missile, and its success depended on its air-launched delivery mechanism.

Similar in significance to the Fritz X, the Azon was the first U.S. guided bomb. The Azon, first used in combat when it was dropped from B-24 Liberator bombers in May 1944, featured radio-controlled flight surfaces on its fins that allowed bombardiers to influence the vertical trajectory of the bomb [24]. The Azon enabled the U.S. to more accurately bomb narrow structures, particularly bridges, in Japanese-held territory. An Azon destroyed the infamous Kwai River bridge, for instance. Though it allowed control only for its vertical axis, the Azon nonetheless stands as a milestone in American development of air-launched guided munitions. The Azon was a flying bomb in its own right.

\footnotetext{
${ }^{7}$ An Ohka suicide aircraft sank U.S. destroyer USS Mannert L. Abele.
} 


\section{E. Epilogue}

By the time WWII ended on September 2, 1945, the war had sparked a myriad of advances in guided munitions. Many, if not most of those advances were enabled by or even fundamentally built around air-launch. Air-launch in WWII helped established a foundation for guided weapons systems, a legacy that continues today.

\section{Commercial Transport Air-Launch}

"Just how strong was the momentum in aviation during the 1930s and how imperative the achievement of ever longer and more ambitious routes was considered, can be gauged from one of the most ingenious projects to be initiated during this most stimulating period in the history of aviation: the Short-Mayo Composite design, launched in 1937" [25]. This unique composite aircraft was developed by the Short-Mayo Composite Aircraft Co. Ltd., which was specially formed in 1935 to develop the system. The composite aircraft was based in the United Kingdom and was in service from January 1938 through January 1939.

The system was composed of the Short S.20 seaplane Mercury fixed atop the Short S.21 flying boat Maia. This composite aircraft was dubbed the Short-Mayo, because Short Brothers company was entrusted with its production and because it was built "to test [Major] R. H. Mayo's theory for extending the range of one aircraft by assisting it into the air on the back of a larger, lightly loaded type" [26].

Mercury on her own was quite capable, but when loaded to her full up-and-away capacity, was not able to takeoff from the water due to her heavy weight. With the help of Maia, Mercury was able to takeoff at her full weight capacity of 47,500 lb. Employing this takeoff method, Mercury established a world's long-distance record for seaplanes, when on October 6, 1938, she flew 6045 miles non-stop from Dundee, Scotland to the mouth of the Orange River in South Africa [26].

The first flight of the Short-Mayo composite occurred on January 21, 1938. ${ }^{8}$ The first successful in-flight separation of the two aircraft occurred on February 6, 1938. Afterward, the composite was used for commercial trans-oceanic service until its final flight on January 12, 1939. After its last flight, the Short-Mayo composite was separated forever. Mercury was pressed into service in a seaplane reconnaissance unit until she was scrapped by the Royal Air Force (RAF) in 1941. Maia was used for navigation training, but on May 11, 1941, was destroyed in Poole Harbour, England, as a result of enemy action [26].

\section{Released to Discover: Air-Launch in Experimental Flight}

For over seven decades, air-launch has enabled flight researchers to simplify experimental aircraft, enhance vehicle performance, and focus flight tests on test objectives. This air-launch research has been utilized in the quest to achieve and refine supersonic flight and in the development of unique space flight systems. Air-launch has been a key enabler to the history of experimental flight, and stands primed to continue that role.

The quest to fly faster than the speed of sound did not begin with the Bell X-1 airplane made famous by Chuck Yeager. Others attempted the feat before Yeager, but many of those aircraft were based on conventional aircraft design. For example, the de Havilland DH 108 prototypes TG 306 and VW120 were specifically designed for highspeed testing, but were based on the conventional de Havilland Vampire jet fighter engine and fuselage. The TG 306 prototype was the first British attempt to achieve supersonic flight in a dive, but broke apart in flight and crashed, killing the pilot. The Americans, however, took a different tack.

\section{A. U.S. Research}

After WWII, the U.S. Government through NASA and the military, began an extensive program of flight research and development of jet- and rocket-powered vehicles. The impetus for this flight research and these developments was the unmitigated desire to fly higher, faster, and farther. The flame of that desire was stoked by the winds of the Cold War. Air-launch lent itself to the U.S. in making great aerospace achievements.

\section{X-1 Research Aircraft}

The Bell Aircraft Company designed the X-1 research aircraft with a liquid-fueled rocket to attempt to exceed the speed of sound in a climb rather than the dive attempted by de Havilland. The X-1 aircraft were powered by a 4-chambered liquid oxygen and alcohol powered XLR-11 rocket engine [27]. Officially designated the XS-1 ( $X$ for "experimental" and $S$ for "supersonic"), the "S" was dropped from the designation three years after the program started [27]. Because the flights of the X-1 aircraft were to be conducted at 45,000 feet and because of the limited burn time of the four rocket motors, Bell elected to carry the X-1 aircraft aloft to 25,000 feet with a "mother ship."

\footnotetext{
${ }^{8}$ Reference 25 claims that the first flight of the composite was January 20, 1938.
} 
This efficient air-launch methodology carried through to many of the subsequent high-speed flight tests of the " $\mathrm{X}$ " aircraft.

On October 14, 1947, the bullet-shaped Bell X-1 aircraft, piloted by United States Air Force (USAF) Captain Charles "Chuck" Yeager, dropped from a B-29 Superfortress bomber, fired its rocket engine and became the first manned aircraft to break the sound barrier in level flight [28]. Air-launch provided the X-1 aircraft with weight reductions as well as speed and altitude boosts in order for it to achieve supersonic flight.

\section{D-558 Research Aircraft}

With the success of the X-1 airplane, researchers around the world continued to make airplanes fly faster and higher. Air-launch became a common technique for much of the high-speed aeronautical research in the U.S.

The Douglas D-558-2 Skyrocket, which in 1953 became the first aircraft to exceed Mach 2, took advantage of air-launch using a U.S. Navy P2B Superfortress patrol bomber [29]. The D-558-2 Skyrocket was born from the Douglas D-558-1 Skystreak which was designed to take off from the ground under its own power. The D-558-2 Skyrocket was unique in that it carried both jet and rocket engines. Unlike the straight winged X-1 airplane, the Skyrocket had swept wings and was used to test dynamic stability, and various control surface configurations. The first 15 flights of the D-558-2 Skyrocket, where the aircraft took off from the ground, were conducted by the Douglas Aircraft Company, but the aircraft was subsequently modified for air-launch. Although it only flew from 1949 to 1956, the Skyrocket provided invaluable data for the development of future supersonic aircraft.

\section{X-2 Research Aircraft}

The Bell X-2 aircraft, first flown unpowered in 1952, launched from a B-50 Superfortress bomber and soon expanded the USAF and the National Advisory Committee on Aeronautics (NACA) Mach 2-plus experience base [30]. Despite achieving Mach 3 flight, the story of the X-2 aircraft is grim. Only 2 were built and both were destroyed in tragic accidents with loss of life. The second accident took the life of test pilot Mel Apt shortly after he had achieved Mach 3 flight. Apt attempted to eject from the aircraft jettisoning the nose compartment. Unfortunately, he was unable to extricate himself and deploy his personal parachute. He died on impact [31].

\section{Missiles}

As supersonic flight matured, missile technology likewise advanced via air-launch tests. The X-7 "Flying Stove Pipe,” a prototypical AQM-60 Kingfisher missile defense target drone first launched in 1951, flew from a Boeing B-50 Superfortress [32]. The X-9 Shrike prototype surface-to-air missile was first launched in 1949 from an EB-50D, another Superfortress variant [33].

\section{At the Edge of Space: $X-15$ Research Aircraft}

The convergence of aeronautical innovation and improved missile technology allowed flight to extend into space. Air-launch played a vital role in developing space access.

The rocket-powered North American X-15 suborbital spaceplane, first flown in 1959, was air-launched from a B-52 Stratofortress bomber (The Boeing Company, Chicago, Illinois). Tested by the National Aeronautics and Space Administration (NASA) as well as the USAF and the U.S. Navy, the vehicle could reach a top speed of Mach 6.72 and a top altitude of $107.8 \mathrm{~km}$ (an altitude above the officially recognized height required for spaceflight). The X-15 suborbital spaceplane made a number of advances, including gathering initial data on the hypersonic flight regime, being the first space vehicle to use a reaction control system for attitude control, and in the case of X-15 pilots, prompting the first use of practical full-pressure suits. The X-15 air-launched flight plan afforded the vehicle greater speed and altitude as well as lower weight than would be needed for ground takeoff capability. The X-15 main landing gear was skids, relegating weight required for wheels and tires to only the nose gear [34]. In many ways, the support of the B-52 bomber mothership was as essential to the record-setting history of the X-15 aircraft as was the X-15 design itself. Air-launch was vital to NASA and USAF efforts to develop more efficient access to orbit, particularly in the form of reusable orbital spaceplanes.

\section{The Lifting Bodies}

NASA built a series of manned lifting body test vehicles beginning in 1963. The vehicles, which unconventionally generated lift from their bodies versus from wings, incorporated key aerodynamic innovations that would help make orbital spaceplanes, particularly the later space shuttle orbiter, into reality. The NASA M2-F1 test vehicle was the first lifting body design. First flown in 1963 via tow by a Pontiac convertible sports car, the M2-F1 vehicle later that year had its first free flight after being towed aloft and released by a NASA C-47 Skytrain aircraft. Air-launch allowed the M2-F1 vehicle to be built as an unpowered test vehicle out of steel tubes and wood for 
around $\$ 30,000$ [35]. The lack of an engine allowed the test program to focus on the aerodynamics of the lifting body shape and avoid the complexity and cost of outfitting the vehicle for powered flight.

Once the M2-F1 vehicle verified the soundness of lifting bodies, NASA followed it with other lifting bodies designs that flew from 1966 to 1973: the Northrop M2-F2 and HL-10 designs, the joint NASA / USAF X-24 program, and the Northrop M2-F3 design. All of these lifting body vehicles were air-launched via a B-52 Stratofortress. Though the M2-F2 vehicle was unpowered, the HL-10, X-24, and M2-F3 vehicles were all rocketpowered, proving that lifting bodies could sustain powered flight [35]. In the case of powered flights, air-launch once again provided enhanced speed, an altitude boost, and reduced weight of the test vehicles.

\section{7. $M-21$ and D-21Aircraft}

Beginning in 1964, the Lockheed M-21 carrier variants of the A-12 Oxcart reconnaissance aircraft as well as B-52 Superfortress motherships tested the Lockheed D-21 reconnaissance drones using air launch. However, the D-21 program was largely unsuccessful, suffering a fatal loss of an M-21 carrier aircraft and never marking a successful operational flight [36].

\section{HiMAT}

The NASA Highly Maneuverable Aircraft Technology (HiMAT) program tested advanced fighter technologies via an unmanned test vehicle air-launched from a B-52 Stratofortress. HiMAT improved digital flight control systems and featured an innovative composite airframe. By air-launching, the vehicle gained altitude and speed, and had reduced system weight to allow researchers to focus flights on the test objectives of the project [37].

\section{Hypersonic Air-Breathers: X-43A and X-51Research Vehicles}

Air-launch enabled pioneering flights of supersonic combusting ramjets, or scramjets. The NASA scramjetpowered X-43A research vehicle (Micro Craft, Inc., Tullahoma, TN), first flown in 2001, was accelerated to flight speed via a Pegasus rocket (Orbital Sciences Corporation, now Orbital ATK, Dulles, Virginia) air-launched from a B-52 Stratofortress. The X-43A research vehicle holds the world record speed for an air-breathing aircraft, Mach 9.6 [38]. Similarly, the scramjet equipped X-51 research vehicle (The Boeing Company, Chicago, Illinois), first flown in 2010, used an air-launched booster rocket to accelerate to flight speed [39]. Both X-43A and X-51 research vehicles required speeds and altitudes only reachable by air-launched rockets to properly meet their test objectives. In both cases, air-launch allowed the vehicles to be relatively small and designed only to address specific test objectives versus if they were built to conduct ground takeoff.

\section{B. British Research}

The British-designed Miles M.52 research aircraft, which began development in 1943, was intended as a Mach 1.3-capable, jet-powered aircraft. The design featured a number of notable innovations, including a sharp leading edge on its wings, a conical nose, and an all-moving tail essential for supersonic flight [40, 41]. Unlike the X-1 research aircraft, the M.52 research aircraft was designed for ground takeoff [41]. The British government cancelled the project in 1946 due to budget constraints. However, the project was revived in a downscaled form in 1947. A De Havilland Mosquito multi-role aircraft launched subscale, rocket-powered models of the M.52 research aircraft. The first model launch was unsuccessful, but the second and final achieved Mach 1.38 [40]. Air-launch helped the M.52 program downgrade to less-expensive rudimentary subscale models, incapable of independent ground takeoff, that still proved the fundamental aerodynamic advances of the program.

\section{French Research}

In 1938, French engineer René Leduc designed a ramjet-powered, air-launched aircraft, the Leduc .10, to research supersonic flight. The outbreak of World War II delayed the first powered flight of the aircraft until 1949. The .10 launched from the back of a Sud-Est Languedoc airliner at just over 10,000 feet altitude, which gave the aircraft ramjet the airspeed needed for startup. Leduc continued his ramjet-powered designs with the Leduc .21 aircraft, which also was air-launched, and the Leduc .22 aircraft, which introduced a turbojet that permitted the vehicle to take off and climb under its own power before igniting its ramjet. Ironically, none of Leduc's designs actually achieved supersonic flight. The .10 and .21 aircraft were subsonic by design with an eye toward edging closer to supersonic flight, while the .22 aircraft was intended to reach Mach 2, but was confined to subsonic flight by its high drag [42]. 


\section{Russian Research}

The latter days of WWII saw Germany attempt construction of the DFS 346 aircraft, a manned, rocket-powered aircraft intended to go supersonic. The DFS 346 aircraft was designed to separate from a German carrier aircraft, ignite its rocket engine, and soar to high altitude at a top speed of Mach 2. As with the X-1 research aircraft, the DFS 346 aircraft was designed to use air launch to boost its performance in order to reach supersonic flight. Soviet forces captured the aircraft wind tunnel models when they conquered Germany [43]. In 1946, the Soviets restarted the project under the name "Samolyot 346" [44]. Echoing the Bell X-1 research aircraft, the Soviets launched the DFS 346 aircraft from a captured American B-29 Superfortress. The DFS 346 aircraft first flew unpowered in 1948. The aircraft was nearly uncontrollable and suffered gear collapse resulting in extensive damage on its first flight. Subsequent flights, including powered flights, were similarly disastrous. A 1951 crash resulting in loss-of-vehicle prompted cancellation of the project. The DFS 346 aircraft never exceeded Mach 1 [43].

In September 1945, the Soviet Design Bureau OKB-256 was directed to build a test aircraft that could be used to test straight, aft-swept, and forward-swept wings at transonic Mach numbers. Chief Designer Pavel Vladimirovich Tsybin directed the design and construction of two unique transonic research aircraft which were towed to altitude and released, dived at steep dive angles with jettisonable water ballast, and were unpowered except for the addition of a short burn solid rocket motor to increase the dive speed. The gliders were constructed out of wood, and originally three aircraft were planned: the LL-1 aircraft with a straight wing, the LL-2 aircraft with a 30-deg aftsweep wing, and the LL-3 aircraft with a 40-deg forward-sweep wing. The LL-2 aircraft was not completed as there was already a considerable amount of aft-sweep wing data available. The LL-1 straight wing and the LL-3 forwardsweep wing aircraft were completed and flown. While they did not exceed Mach 1, they did reach Mach numbers as high as Mach 0.97 [45].

The LL-1 and LL-3 aircraft used a two-wheel dolly that was jettisoned after take-off, and were then towed to 5-7 km (16,400-23,000 ft) altitude, at which point the tow line was released, and the aircraft started a steep dive to the transonic test point. To increase the aircraft dive speed, $2000 \mathrm{lb}$ of water ballast were carried, and the short burn solid rocket motor provided an additional increase in the dive speed. Test instrumentation and cameras photographing tufts on the wing were turned on at the test point. The water ballast was then dumped, and the aircraft glided to an unpowered landing, with the aircraft landing on a central retractable skid [45].

The combination of air-launch by towing the aircraft to altitude, combined with a steep dive angle (45-60 deg) with water ballast and a short burn solid rocket motor allowed Mach numbers as high as Mach 0.97 to be reached. This approach also greatly reduced the cost of the program compared to having a specially configured mothership for direct carry of the aircraft, and having to install in the aircraft a complex liquid rocket engine, as was used on the U.S. X-1 research aircraft. The Tsybin LL-1/LL-3 program was considered by the Russians to be a very successful program [45].

\section{E. Space Vehicles}

Air-launch has been employed in the flight testing of several earth-returning space vehicle concepts. These flight tests have been primarily focused on low-speed maneuvering and the approach and landing phase of flight.

\section{Space Shuttle Approach and Landing Tests}

The lifting body legacy directly influenced the design of the NASA Space Transportation System Orbiter Vehicle, commonly known as the Space Shuttle orbiter [35]. Leading up to the 1981 maiden flight of the shuttle, NASA conducted the Approach and Landing Test (ALT) program on the prototype orbiter Enterprise. Because the shuttle orbiter was designed as a glider for its entry and landing from orbit, NASA opted to carry Enterprise aloft via a modified Boeing 747 airplane and release the orbiter, manned, to conduct its landing tests. Using an existing aircraft to give the orbiter the speed and altitude needed for flight allowed ALT researchers to focus solely on their test objectives and avoid the cost, risk, and time delay of modifying the orbiter with jet engines or other means for ground takeoff. ALT successfully paved the way for the shuttle program, which fulfilled the NASA pursuit of a reusable orbital spaceplane [46].

\section{NASA X-38 Crew Return Vehicle Prototype}

After ALT, air-launch kept a central place in space vehicle development. The NASA X-38 vehicle was a prototype of the Crew Return Vehicle (CRV) a lifting body meant to evacuate crew from emergencies aboard the International Space Station (ISS). The X-38 vehicle first flew in 1999 in an air-launch from a B-52 mothership. Like the Space Shuttle, the CRV was meant to land as an unpowered glider, but it differed in that its final descent was 
guided by a parafoil, and it featured landing skids versus wheeled gear [47]. Thus, the X-38 vehicle was airlaunched versus outfitting the vehicle for independent ground takeoff.

\section{The $X-40 A$ and $X-37$ Vehicles}

Similarly, the Boeing X-40A vehicle, meant to test a reusable orbital spaceplane, was glide-tested from a helicopter and swooped to an unpowered landing [48]. The Boeing X-37 vehicle, a larger derivative of the X-40A, in 2006 also was glide-tested. The X-37 later developed into the X-37B, which has completed four successful orbital missions, including four successful autonomous landings, proving the usefulness of the X-40A and X-37 airlaunched glide tests [49][50]. (See more detailed information about the X-37 in section IX (I) below.)

\section{The Dream Chaser Engineering Test Article (ETA)}

Today, Sierra Nevada Corporation (SNC) (Sparks, Nevada) is developing the Dream Chaser, a lifting body spaceplane built to service the ISS through the NASA Commercial Resupply Services program. To test out the Dream Chaser approach and landing dynamics, SNC developed the Dream Chaser engineering test article (ETA), which shares a nearly identical aerodynamic shape to the Dream Chaser, but is a low-speed, low altitude, non-spacerated version of the spaceplane. The ETA was first drop tested from a helicopter in 2013 at Edwards AFB. The ETA will be drop tested again at Edwards AFB prior to an anticipated orbital test flight of Dream Chaser sometime before 2020. Since Dream Chaser is an unpowered glider on landing, air-launched landing tests were a logical choice for it [51].

\section{Foreign Experimental Space Vehicle Tests}

Outside the United States, there have been relatively few air-launched experimental space vehicle tests. The Soviet MiG-105 vehicle, also known as Spiral, was a prototype for an orbital spaceplane and first flew in 1976 independently via jet power. In 1977, the airplane was dropped from a Tu-95K bomber and landed on skids, demonstrating weight savings from avoiding wheels and tires [43]. The European Space Agency (ESA) used air launch to test the landing of both the cancelled Hopper spaceplane in 2004 and the Intermediate eXperimental Vehicle (IXV) spaceplane in 2012 and 2013 [52]. In both cases, air launch was a logical test choice because the vehicles would have been gliders for their planned operational missions. The IXV launched on a suborbital trajectory into space in 2015 aboard an ESA Vega rocket and successfully reentered the atmosphere of Earth before splashing down in the ocean for recovery [52].

\section{Parasite Aircraft}

This section deals specially with the topic of parasite aircraft. By "parasite aircraft," we mean a multi-air-vehicle configuration where a large air-vehicle hosts one or more smaller air-vehicles and the primary mode of operation is for these air-vehicles to stay connected together in flight. These parasite vehicles are included in this paper on airlaunch because during the course of a flight operation, the parasite vehicles eventually "launch" from the larger host air-vehicle. An example of this parasite aircraft configuration is the Akron-class airships that carried fighters (Section III). There are other notable parasite configurations addressed in this current section.

\section{A. Wingtip-Coupled Configurations}

Starting in 1949, the USAF began a series of tests where small aircraft would be coupled to the wingtips of a larger aircraft. The theory was that joining a small aircraft to each wingtip of a large aircraft would increase the wing aspect ratio of the large aircraft, decreasing its induced drag, and thereby extending its range. The USAF tested this theory on a bomber-fighter configuration. In this synergistic configuration, the bomber would carry wingtip-attached fighter escorts along on a mission. The bomber-host would provide increased range to the fighter-escorts, and the escorts would provide protection to the bomber [53].

\section{C-47A Skytrain / Q-14B Cadet}

The wingtip-coupled flight experiments began with a twin-engine C-47A Skytrain cargo airplane and a Q-14B Cadet light, single-engine aircraft. Testing of this configuration occurred from August 19 through October 18, 1949. Testing revealed that in-flight coupling and de-coupling of the Cadet and Skytrain was feasible. In all, 231 couplings were made for over 28 hours of coupled flight time. The tests identified major operating modes and pilot techniques and formed the basis of knowledge for flight testing of other wingtip-coupled configurations [53]. 


\section{Project MX1016 B-29 Superfortress / F-84 Thunderjet Wingtip Towing}

In the summer following the C-47 Skytrain / Q-14 Cadet wingtip coupling tests, testing began on a B-29 Superfortress / F-84D Thunderjet combination. From July 21 through October 20, 1950, one- and two-parasite configurations were tested. In all, 43 wingtip couplings were performed resulting in 15 hours of coupled flight-test time. The overall result was that a B-29 Superfortress could carry two F-84 fighters with only a small loss in range to the bomber, but a distinct increase in range to the fighters.

A follow-on flight-test program of this configuration was conducted to investigate a sophisticated automatic flight control system that would keep the host and parasite aircraft well coordinated when coupled. Approximately 6 test flights of this configuration were made in March and April 1953. On April 24, 1953, Project MX1016, as it was called, came to an end. The test was in a single-parasite configuration. When the F-84 Thunderjet momentarily engaged its automatic flight control system, it experienced a violent pitching motion, causing it to roll into the B-29 wing, causing severe damage to both aircraft. Both aircraft and their crew were lost in this accident [53].

\section{Tom-Tom B-36 Peacemaker / F-84 Thunderflash}

Project Tom Tom was refinement of earlier wingtip-tow configurations. In Tom-Tom, an RF-84F Thunderflash ${ }^{9}$ was wingtip-coupled to a B-36 Peacemaker. This configuration was to be the most highly integrated. "The B-36 system included provisions to launch and retrieve the fighters in flight, and to provide fuel, pressurization, and heating air to the parasites while coupled" [54] [p. 184]. The objective of this configuration was for the most efficient escort of the parasite. To this end, the F-84 Thunderflash was to shut down its engine once it was attached to the host. Testing began on November 2, 1955, and continued until September 26, 1956. In this time, only a few coupling attempts were made, as "wingtip vorticies and turbulence made this operation a very dangerous affair" [54] [p. 184].

\section{B. XP-85 Fighter Aircraft and the Fighter Conveyer Project}

With the Akron-class airships, the U.S. Navy envisioned a "lighter-than-air carrier" that could ferry fighter-scout aircraft long distances to the theater where they were needed. Similarly, the U.S. Army Air Force envisioned a bomber that could ferry a fighter-escort longer distances than the fighter could fly on its own. In January 1944, prior to the end of WWII, the AAF invited industry to submit proposals for parasite jet fighters. "The McDonnell Aircraft Corporation was the only company to respond, and proposed a small fighter aircraft to be carried partially inside a parent B-29, B-35, or B-36 heavy bomber" [54] [p. 171]. The AAF rejected this proposal and subsequently dictated that the parasite fighter would have to be carried entirely within a B-35 or B-36 heavy bomber.

\section{XP-85 "Goblin" Parasite}

McDonnel came back with a proposal for a small, egg-shaped jet fighter that fit within the bomb bay. To fit within the bay, the airplane included a unique triple vertical tail and folding wings. The AAF accepted the idea and ordered two aircraft that were designated "XP-85."

The XP-85 fighter aircraft was fitted with a retractable hook that would engage a trapeze apparatus on the belly of the bomber. The newly formed USAF began trials of this configuration on August 23, 1948, using a modified B-29 bomber. ${ }^{10}$ Hook-ons were very difficult with this configuration due to turbulence as the XP-85 aircraft approached the trapeze. As a result, one XP-85 aircraft made only 7 free-flights, with only three successful hookons; the other XP-85 aircraft made only one free-flight test. The flight-test program ended on April 8, 1949 [54].

\section{The Fighter Conveyor Project}

The Fighter Conveyor project (FICON) was a follow-on to the XP-85 project. The difficulties encountered during the XP-85 trials were attributed to the unique shape of that aircraft, derived from the AAF requirement for the fighter to fit within the bomb bay of the host. The USAF relaxed this requirement in order to utilize a more conventional fighter. The subsequent tests were called the FICON project, where an F-84 fighter was mated to a B-36 host. As with the XP-85 project, the host was fitted with a trapeze apparatus, and the parasite was fitted with a hook apparatus first on the nose, then eventually on the fuselage forward of the canopy. The hook and trapeze designs were both modified over the course of the flight-test program until adequate hook-on dynamics were achieved.

\footnotetext{
${ }^{9}$ The Thunderflash was a swept-wing variant of the F-84 fighter.

${ }^{10}$ A B-29 bomber was used because the B-36 bomber was not available, and the B-35 bomber was not produced past the YB-35 prototypes.
} 
Testing of the FICON configuration began in early 1952. By 1954, the USAF had awarded a contract to Convair to modify 10 RB-36D bombers to the FICON configuration. The first FICON-equipped B-36 bomber was delivered to the USAF in February 1955. Operationally, the FICON configuration supported both the RF-84F Thunderflash, capable of carrying an atomic weapon, and the RF-84K reconnaissance aircraft. When the U-2 spy plane entered service in 1957, the FICON configuration was phased out of service [54].

\section{Epilogue}

Ultimately, in-air refueling systems rendered the bomber-fighter parasite configurations obsolete. No further parasite configurations intended to extend flight range have flown since FICON.

\section{Air-Launch for Space Access}

The advantage of using one air vehicle to enhance the performance of another air vehicle has also been considered and utilized for space launch. There are several air-launch systems, both suborbital and orbital, that have been tested and developed in the past, or that are being developed or envisioned for the future. In this section, we will examine the most prominent examples of air-launch for space access.

\section{A. Project Pilot}

In the summer of 1958, the Naval Ordnance Test Station (NOTS) in China Lake, California, made several attempts to air-launch a small satellite into orbit. "Project Pilot" was a classified project to place a satellite into orbit using a 5-stage, all-solid rocket booster air-launched from the wing of a Douglas F4D-1 Skyray. "Their inspiration was to put up a response to Sputnik" [55] [p. 5] and to "put rapid, all-access to orbit in the hands of naval forces worldwide" [55] [p. 1].

The project was nicknamed "NOTSNIK," giving a nod to its development house and to the history-altering event that motivated its development. The project was initiated by a group of NOTS physicists after the successful launch of Sputnik in October 1957. In February 1958, the Bureau of Ordnance in Washington approved \$300,000 in startup funds. In May 1958, NOTS received more substantial funding, eventually totaling over $\$ 4$ million, to enable it to build hardware and perform the ground and flight-test programs. NOTS sold the project under the auspices that the Navy could deploy satellites to monitor Project Argus, a series of high-atmosphere nuclear test explosions. Unfortunately, Argus was set to occur in August 1958, which gave NOTS just a few precious months to execute the project [55] [p. 2].

However, by late July 1958, NOTS was attempting its first air-launch off the coast of California. In all, six airlaunch attempts were made between July 25 and August 28, 1958. The third and possibly only successful air-launch attempt $^{11}$ occurred on August 22. A tracking station in Christchurch, New Zealand, reported receiving the NOTSNIK radio signal on what would have been the first and third passes over the station. No other passes were detected. Some at NOTS were skeptical. "Privately, the NOTS management did not believe the satellite entered orbit. The signals were so faint that they may have been nothing more than a case of wishful thinking on the part of the operating technicians" [56] [p. 61].

NOTS envisioned that an air-launch capability like NOTSNIK would be part of the Navy munitions livery, available on the shelf to put small satellites into orbit when needed [55] [p. 5]. That vision did not come to fruition.

\section{B. Project Caleb}

After the NOTSNIK flight-test program, NOTS embarked on Project Caleb, a larger, four-stage design using a more powerful F-4 Phantom as the launch platform [55] [p. 8].

The NOTS-EV-II Caleb / NOTS-500-Hi-Hoe air-launched launch vehicle and anti-satellite interceptor was developed from the NOTS-EV-I ${ }^{12}$ Pilot five-stage solid air-launched satellite launch vehicle. Caleb was originally designed as a fast-response orbital launch system to put small military satellites into orbit on short notice, and was originally designed as a four-stage solid rocket system. The actual Caleb and Hi-Hoe launches utilized two stage solid rocket systems intended for anti-satellite and sounding rocket purposes. ${ }^{13,14}$ The NOTS-500-Hi-Hoe airlaunched launch vehicle used a F4H Phantom II launch aircraft which provided greater performance.

\footnotetext{
${ }^{11}$ Launch number 1 , July 25, 1958, may have been successful also, but there was insufficient tracking data to verify success [55] [p. 60].

12 The name NOTS-EV-I was retroactively applied to NOTSNIK.

${ }^{13} \mathrm{http}: / /$ www.designation-systems.net/dusrm/app4/caleb.html [retrieved 10 July 2017]

${ }^{14}$ https://en.wikipedia.org/wiki/NOTS-EV-2_Caleb [retrieved 10 July 2017]
} 
For the original Caleb four-stage solid orbital launch system, air-launch was used for its performance advantages, in particular the performance advantage of being launched from a fighter jet class aircraft in a zoom climb, releasing the launch vehicle at a steep flight path angle. For the two-stage solid anti-satellite interceptor configuration, the fighter air-launch conferred the performance advantages of air-launch, but did not need to achieve orbital velocity, it just had to achieve the orbital altitude of the satellite being intercepted.

\section{F-104 Air-Launched Sounding Rocket}

While Project Caleb was still operating at China Lake, just 65 miles south at the NASA Flight Research Center (FRC) at Edwards AFB in California, engineers were testing the launch of a sounding rocket from the centerline of an F-104A Starfighter. The overall purpose of the tests was to "investigate some of the operational aspects and the practicability of using the energy input of the airplane as a first-stage booster for sounding rockets" [57] [p. 1]. The larger goal was to demonstrate the operational utility of using an airplane to launch a rocket into space: "The apparent benefits provided by an airplane-rocket combination were a recoverable first-stage booster [the airplane], a means of controlling the flight parameters at second-stage [rocket vehicle] ignition, and a highly flexible launch site that can be located anywhere within the aircraft range" [57] [p. 1].

Two separate payloads were used on the sounding rocket test vehicles. One was a meteorological payload that tested the capability to make atmospheric measurements at altitudes where the X-15 research aircraft would fly, above 100,000 feet, the practical limit of observation balloons. The second payload was a classified payload from NOTS.

In all, five flights were made: four with the meteorological "model A" payload and one with the NOTS "model B" payload. Some of these flights were made in the vicinity of FRC and some in the Pacific Missile Range off of Point Magu on the California coast.

\section{Ballistic Missiles}

In the late 1950s into the early 1960s the U.S. worked on the development of air-launched ballistic missiles under the Weapon Systems 199 (WS-199) program. Two test missiles were flown: the WS-199B Bold Orion, which was air-launched from a Boeing B-47B Stratojet bomber and consisted of a Sergeant solid propellant first stage and an Altair solid propellant second stage, and the WS-199C High Virgo, also using Sergeant and Altair first and second stages, which was air-launched from a Convair B-58 Hustler bomber. ${ }^{15,16,17}$

The Bold Orion and High Virgo air-launch test missiles supported the development of air-launch ballistic missiles, where the missile could be reduced in size due to the performance advantages of air-launch, and the aircraft launch platform would function as a mobile launch site. With the Altair second stage the Bold Orion operating as an air-launched ballistic missile had a range of $1600 \mathrm{~km}$ (1000 miles).

These test missiles were also used for early anti-satellite interceptor tests, where the performance advantage of air-launch reduced the required size of the missile for a given payload. For both the air-launch ballistic missile mission and the anti-satellite interceptor mission the missile did not need to reach orbital speed; sub-orbital speeds were sufficient to meet the range requirements for the ballistic missile, and to reach the orbital altitude of the satellite being intercepted. These early anti-satellite interceptor concepts were to use small nuclear warheads where the anti-satellite interceptor only had to pass by the satellite within the kill radius of the nuclear warhead. The final test launch of a Bold Orion missile on October 13, 1959, was an anti-satellite interceptor test. The Bold Orion was launched from the B-47B launch aircraft at 11,000 meters (35,000 ft), and passed within $6.4 \mathrm{~km}$ (4 miles) of the Explorer 6 satellite, which would have been within the kill radius of a small nuclear warhead, if one had been fitted to the missile. This test launch of Bold Orion was the first demonstrated interception of a satellite by either ground launch or air-launch. The High Virgo missile was also used for anti-satellite interceptor tests. The fourth High Virgo launch on September 22, 1959, was an anti-satellite interceptor test. After being launched from the B-58 launch aircraft at Mach 2, the Explorer 5 satellite was targeted, but the telemetry signal was lost, and camera film which was to record the interception was not recovered.

The air-launch ballistic missile concept was developed into the Douglas GAM-87 Skybolt missile, a two-stage solid propellant missile. The Skybolt air-launch ballistic missile flew a Mach 12.4 (9500 mph) ballistic trajectory, and had a maximum range of $1850 \mathrm{~km}$ (1150 miles). ${ }^{18}$ The tailcone on the end of the missile reduced the missile

\footnotetext{
15 http://www.designation-systems.net/dusrm/app4/ws-199.html [retrieved 10 July 2017]

${ }^{16}$ https://en.wikipedia.org/wiki/Bold_Orion [retrieved 10 July 2017]

${ }^{17}$ https://en.wikipedia.org/wiki/High_Virgo [retrieved 10 July 2017]

${ }^{18} \mathrm{https} / / /$ en.wikipedia.org/wiki/GAM-87_Skybolt [retrieved 10 July 2017]
} 
drag while being carried by the launch aircraft, thus minimizing the decrease in aircraft range from the additional drag of carrying the missile. The tailcone was jettisoned upon ignition of the first stage solid rocket motor.

In addition to the B-52 bomber, the Skybolt was also to have been used on the British Avro Vulcan bomber. Skybolt test missiles were only launched from B-52 bombers. The Skybolt test program suffered a series of failures with the first 5 flights being unsuccessful, combined with cost and political factors; the result was the cancellation of the program. Ironically, the first successful Skybolt flight occurred the day after the program was cancelled.

A later air-launch ballistic missile concept was the concept of an inter-continental ballistic missile (ICBM) launch from a carrier aircraft using a parachute air-drop. This concept was actually tested with a Boeing Minuteman I missile using a partially-fueled first stage, and dummy second and third stages, air-dropped from a Lockheed C-5A Galaxy transport aircraft. ${ }^{19}$ The test drop was performed on October 24, 1974. The Minuteman I missile was dropped from the C-5A aircraft at 20,000 ft. The parachutes stabilized the missile in the upright position and the partially-fueled first stage was ignited when the missile had descended to $8000 \mathrm{ft}$. There was a small performance benefit from igniting the first stage at $8000 \mathrm{ft}$ altitude compared to a ground launch, but the primary benefit of the concept was using an aircraft as a mobile launch site for a full-size ICBM. Operational deployment of the airdropped ICBM was not pursued due to engineering and security concerns.

\section{E. ASM-135 Anti-Satellite Missile}

In 1978, U.S. President Jimmy Carter issued a Presidential Directive that led to the establishment of an American anti-satellite (ASAT) system. This directive was prompted by a new threat to U.S. reconnaissance capability, a Soviet anti-satellite weapon. ASAT system development continued into the 1980s. In 1983, the Reagan Administration requested $\$ 218$ million to further ASAT development. The Administration felt that ASAT technology was an essential ingredient to strengthen the nation's nuclear deterrent. The U.S. ASAT weapon was "intended to destroy Soviet satellites that guide nuclear missiles, provide communication with bombers or attack American satellites." 20

Ultimately, the U.S. developed the ASM-135 ASAT missile. The ASM-135 utilized a two-stage solid rocket for boost, and a non-explosive "Miniature Homing Vehicle" for the kill. The missile was designed to be air-launched from the centerline of an F-15 Eagle fighter jet (McDonnell Douglas, now The Boeing Company, Chicago, Illinois). The USAF contracted with LTV Aerospace to build the ASM-135.

In all, five ASM-135s were tested. Flight testing started with a captive carry test in 1982. In early 1984, a test launch was conducted to test the ASM-135 propulsion system. A successful demonstration of the ASAT system was made on September 13, 1985, when an F-15A from Edwards AFB air-launched the ASM-135 over the Pacific Missile Range, destroying an obsolete satellite orbiting 345 miles above. The USAF cancelled the ASAT program in the late $1980 \mathrm{~s}^{21,22}$

\section{F. Pegasus}

On April 5, 1990, Orbital Science Corporation (now Orbital-ATK) air-launched its first Pegasus booster from the wing of a NASA-operated Boeing B-52B mothership affectionately known as Balls 8. Pegasus is a three-stage solid rocket booster developed to deliver to space small satellites of up to $450-\mathrm{kg} .{ }^{23}$ The booster was developed with private funding, but Orbital partnered with the government to conduct the first several flights. The first five flights of Pegasus, as well as flight number 7, were made from Balls 8. The balance of the 43 flights to-date of Pegasus ${ }^{24}$ [58] [p. 1] were launched from a specially modified Lockheed L-1011 transport aircraft, dubbed Stargazer.

The fundamental premise behind the development of Pegasus is that "air-launch ... provides a substantial performance improvement over equivalently sized ground-launched systems and also offers new launch operations flexibility, including the ability to launch from remote sites directly into virtually any orbital inclination" [59] [p. 72].

${ }^{19}$ https://en.wikipedia.org/wiki/Air-launched_ballistic_missile [retrieved 10 July 2017]

${ }^{20} \mathrm{http}: / /$ www.nytimes.com/1982/06/06/us/us-plans-weapon-against-satellites.html [retrieved 23 June 2017]

${ }^{21}$ http://web.archive.org/web/20031218130538/http://www.edwards.af.mil:80/moments/docs_html/85-09-13.html [retrieved 23 June 2017]

${ }^{22} \mathrm{https}$ ://airandspace.si.edu/collection-objects/missile-air-launched-anti-satellite-asat [retrieved 23 June 2017]

${ }^{23}$ Pegasus product sheet, http://www.orbitalatk.com/flight-systems/space-launch-vehicles/pegasus/docs/Pegasus_ REV02-17.pdf [retrieved 20 June 2017]

${ }^{24}$ Including Pegasus XL, which was developed to improve capability and operational flexibility. The Pegasus XL vehicle has increased propellant, improved avionics, and a number of other design enhancements. Pegasus XL made its first flight on June 27, 1994, from Stargazer. 
There were market drivers as well. A low-cost launch capability was envisioned that would offer dedicated launch capability to payloads that would otherwise, because of the high cost of a dedicated booster, share the ride with another primary payload. A shared ride puts the secondary payload at the mercy of the primary, which always has its own unique operational, security, and performance requirements. The motivation for low-cost, dedicated launch is summarized:

"Pegasus was designed specifically to reduce or eliminate most of these [rideshare] restrictions and limitations and to provide low-cost dedicated launches for small payloads... [providing] a highly flexible launch system capable of remote basing, rapid launch processing, reduced ground support, and improved range safety.” [59] [p. 74]

Another, more altruistic benefit was envisioned as well:

"The vehicle's remote basing capability provides unparalleled launch flexibility to countries that would like to become involved in space research and civilian small satellite applications. For the first time, countries can design and build small satellites and launch them from their country or nearby open ocean areas without the need to develop expensive range and launch support complexes." [59] [p. 74]

Orbital has flown 43 flights of Pegasus, ${ }^{25}$ and the Pegasus air-launch booster system is still in use today.

\section{G. Aero-Tow Concepts}

In addition to direct-carry space launch systems, there are also examples of space launch systems that utilize aero-tow. Both approaches enjoy the performance advantages of launching high above the ground. In direct-carry systems, however, the carrier aircraft requires significant modification to accomdate the launch vehicle. With aerotow launch systems, a distinct advantage is that the tow vehicle, akin to the carrier aircraft in direct-carry systems, does not require significant modification.

\section{Kelly Space \& Technology Eclipse}

Late in the winter of 1993, Mike Kelly, founder of Kelly Space \& Technology, Inc. (KST) (San Bernadino, California), had the idea to tow a launch vehicle behind a transport aircraft. This idea was motivated by the desire to reduce the cost of putting satellites into orbit. Tucker summarizes Kelly's thinking:

"Despite the rapid growth of Internet and telecommunications technology, despite many breakthroughs in efficiencies that had lowered costs, there had been no breakthroughs in the satellite delivery system. The high cost of launch had not changed for several decades" [60] [p. 1].

As Kelly mulled the possibilities for reduced-cost launch, considering all of the existing launch methods, he ultimately settled on an aero-towed launch vehicle. To see this idea become reality, Kelly formed KST. The KST aero-towed launch system became known as Eclipse.

In 1995, KST was awarded a phase I contract under the USAF Small Business Innovative Research (SBIR) program to study the Eclipse system. KST was later awarded an SBIR phase II contract to research the Eclipse concept in flight. KST worked with the engineers at AFRC to bring this flight research program to reality. This phase II work culminated in six flights between late-1997 and early-1998.

The flights utilized a Lockheed C-141 Starlifter from Edwards AFB connected by a 1000 foot Vectran ${ }^{\circledR}$ rope to a Convair QF-106 Delta Dart from Tyndall AFB (Florida). The QF-106 aircraft, which approximated the Eclipse delta wing configuration, was repurposed from being a target drone destined for obliteration from friendly fire to the role of research spaceship. To end each test, the towed F-106 aircraft would release (air-launch) from the C-141A tow aircraft and land on an Edwards AFB runway. Although the flight testing was successful and the concept proved to be viable, KST was unable to garner sufficient investments to develop the system further.

\section{Towed-Glider Air-Launch System}

Similar to the KST Eclipse idea is an idea called Towed-Glider Air-Launch System (TGALS), ${ }^{26}$ developed at the NASA Armstrong Flight Research Center. The TGALS concept was developed by AFRC engineer Gerald Budd and is patented by AFRC.

This unique approach involves towing behind a conventional airplane an inexpensive, reusable, remotely piloted glider that carries a launch vehicle. This towed glider configuration allows the launch vehicle to carry more payload

\footnotetext{
${ }^{25} \mathrm{http}: / /$ http://www.orbitalatk.com/flight-systems/space-launch-vehicles/pegasus/docs/Pegasus\%20Mission\%20 History.pdf [retrieved 23 June 2017]

${ }^{26}$ This section includes information from the NASA Technology Opportunity Sheet entitled, "Cheaper, Safer, More Efficient Air Launch via Towed Glider." This Technology Opportunity Sheet is available upon request from the AFRC Technology Transfer Office.
} 
to orbit at less cost than is possible with other air-launch techniques or traditional ground launches. The fundamental premise is, as Kelly states, "You can pull more than you can carry" [60] [p. 2].

TGALS uses a transport or business jet-class aircraft with sufficient propulsive thrust to aero-tow to launch altitude a remotely piloted glider with a multi-stage launch vehicle mounted underneath. Once released, the glider uses its own small rocket motor to execute a pull-up maneuver that allows the launch vehicle (with payload) to be released for ignition at an elevated flight path angle. The launch vehicle can be simple and lightweight, since it carries far less propellant than is required for ground-based launch. After the launch vehicle is released for ascent to orbit, the glider returns to Earth where it can be maintained and stored until the next mission.

Some operational advantages of the proposed system are:

1) An air-launched system avoids the costs associated with ground-based pad construction, maintenance, and refurbishment as well as with scrubbed launches caused by inclement weather.

2) The use of existing aircraft for towing significantly reduces development and maintenance costs while simultaneously improving reliability and safety.

3) An towed glider air-launch system can launch greater masses than conventional direct-carry air-launch methods and vertical/ground-launch systems (30 percent and 70 percent more mass, respectively).

In October 2014, AFRC performed initial flight testing of a scaled, twin-fuselage model glider to demonstrate TGALS operation. The demonstration flights were successful.

\section{Post Note}

The KST initial Eclipse tow launch system called for a fully expendable, unmanned, air-launched booster using all solid propellant motors. ${ }^{27}$ The KST Eclipse was the first stage of a launch vehicle system. Whereas the glider in TGALS is the means of carrying a launch vehicle. The glider, in this case, is akin to the $0^{\text {th }}$ stage of the launch system. The fundamental difference between the KST Eclipse and the AFRC TGALS is the Eclipse stage is optimized for the boost task, whereas the TGALS glider is optimized for the task of lifting a launch vehicle and placing it in a pitch up angle conducive for launch of the launch vehicle.

The Eclipse flight test ended in 1998, but KST is still interested in aero-towed launch systems. In 2017, KST entered an exclusive license agreement with AFRC for the TGALS technology. In the agreement, it is incumbent upon KST to identify an investor or investors for TGALS development.

\section{H. SpaceShipOne}

In 1995, a prize concept was created by the X-Prize Foundation to stimulate investment in private spaceflight. In May 2004, the prize was renamed Ansari X-Prize after entrepreneurs Anousheh and Amir Ansari made a multimillion-dollar donation to the prize. ${ }^{28}$ The final prize value was $\$ 10$ million. The challenge: "to build a reliable, reusable, privately financed, manned spaceship capable of carrying three people to 100 kilometers above the Earth's surface twice within two weeks." 29

On June 21, 2004, above the Mojave Air and Space Port (Mojave, California), the world's first privately-funded spaceplane was air-launched from its White Knight mothership into space. The spaceship, christened SpaceShipOne, was the product of Mojave Aerospace Ventures, a joint venture between Burt Rutan's Scaled Composites (Mojave, California and billionaire Paul Allen. Scaled provided the technical know-how to build the spaceship and mothership systems, while Allen provided the funding.

White Knight was a twin-engined jet that would lift SpaceShipOne to 47,000 feet for launch. SpaceShipOne was directly attached to the undercarriage of White Knight and was released in horizontal flight once launch altitude was attained. After release, SpaceShipOne ignited her hybrid rocket motor, then performed a high-g pull-up to nearvertical orientation where she would ascend toward space.

On September 29 and again October 4, 2004, SpaceShipOne ascended above the 100 kilometer goal line. These two successful flights to space by SpaceShipOne earned Mojave Aerospace Ventures the $\$ 10$ million Ansari prize. No subsequent flights of SpaceShipOne occurred.

Although SpaceShipOne had garnered $\$ 10$ million in prize money, it is estimated to have cost $\$ 30$ million to produce. ${ }^{30}$ That SpaceShipOne garnered less prize money than it cost to build is hardly good numbers to a billionaire like Allen or a businessman like Rutan. So what, then, could be the motivation for making such an investment? The answer lies beyond the prize money. Rutan hints at an answer when describing how he came up with the name

\footnotetext{
${ }^{27} \mathrm{http}: / /$ www.kellyspace.com/launchvehicle2/ [retrieved 21 June 2017]

${ }^{28} \mathrm{http} / / /$ ansari.xprize.org [retrieved 21 June 2017]

${ }^{29} \mathrm{http}: / /$ ansari.xprize.org [retrieved 21 June 2017]

$30 \mathrm{https}: / /$ history.nasa.gov/x-prize.htm [retrieved 21 June 2017]
} 
"SpaceShipOne": "And I thought, I don't have any problem calling this SpaceShipOne, because I want to build a SpaceShipTwo, and I want to build a SpaceShipThree" [61] [p. 21]. The Ansari X-Prize and a little vehicle named SpaceShipOne were the impetus for future spaceships that would hopefully someday earn Mojave Aerospace Ventures a profit.

\section{X-37 Spaceplane}

Two years after successfully launching SpaceShipOne on her prize-winning flights, the White Knight mothership was used to perform flight tests of the X-37 spaceplane. The X-37 spaceplane is a space vehicle developed by The Boeing Company under contract to DARPA. The unmanned, reusable spaceplane is launched vertically to space atop an Atlas V launch vehicle and returns from space to land horizontally on a runway. On her first four missions, X-37 spaceplane spent 2086 cumulative days in space, including 718 days on orbit during her most recent mission, which ended May 7, 2017, with a successful runway landing at the NASA Kennedy Space Center (Florida). ${ }^{31}$

Before the first trip of the X-37 spaceplane to space, the White Knight was used to drop (air-launch) the X-37 spaceplane from a high altitude to validate her approach and landing characteristics. Three drop tests were performed. The first drop test occurred on April 7, 2006 at Edwards AFB. Two subsequent drop tests were performed at Air Force Plant 42 in Palmdale, California. These tests occurred on August 18 and September 26, 2006.

\section{J. Under Development}

There are several space-launch systems currently being developed by commercial space companies. A few of these new space-launch systems rely on air-launch and are outlined in this section.

\section{SpaceShipTwo}

In 2004, on the heels of the award-winning flights of SpaceShipOne, Sir Richard Branson launched Virgin Galactic, a company to fly tourists into space. Space travel was part of Sir Richard's thinking long before he witnessed the flights of SpaceShipOne. He had trademarked the name "Virgin Galactic" nearly a decade prior in 1996. But a trademark is not a means of getting to space. Branson needed a space vehicle. He had finally found it in the air-launched SpaceShipOne. Branson had become aware of SpaceShipOne and White Knight when his project manager visited Scaled Composites in 1999 to check the progress of the Virgin Atlantic GlobalFlyer, an airplane that Branson had financed and that would eventually take Steve Fossett on a non-stop voyage around the world [61] [loc. 826].

Scaled Composites was tasked to build the first spaceship for Virgin Galactic and a new mothership to carry it. The new spaceship class, called SpaceShipTwo, was designed to carry two crew and six tourist passengers on a trip above the Karmann line. The first of her class, named VSS ${ }^{32}$ Enterprise, was unveiled on December 7, 2009. ${ }^{33}$ The new mothership class is called WightKnightTwo, a twin fuselage design that carries SpaceShipTwo on a center pylon of the wing between the two fuselages. The first WhiteKnightTwo-class mothership is affectionately called VMS $^{34}$ Eve, after Sir Richard's mum. In 2005, a year after Virgin Galactic was started, The Spaceship Company was formed to build subsequent spaceships and motherships. ${ }^{35}$

Beginning December 21, 2008, VSS Enterprise went through an extensive flight-test program, including several flights captive beneath Eve, as well as several air-launched flights, both unpowered glide flights and flights that utilized the rocket motor. The flight-test program ended October 31, 2014, when on her fourth rocket-powered flight, VSS Enterprise broke up in flight, seriously injuring the pilot and killing the co-pilot. The loss of Enterprise was attributed to an error by the co-pilot in prematurely unlocking the wing feathering system of the spaceship. ${ }^{36}$

At the time of the loss of Enterprise, the next SpaceShipTwo-class vehicle was already working its way through the assembly line at The Spaceship Company. On February 19, 2016, Virgin Galactic unveiled the second SpaceShipTwo, which it christened VSS Unity. ${ }^{37}$ VSS Unity incorporated design changes to prevent what caused

31 https://spaceflightnow.com/2017/05/07/x-37b-spaceplane-returns-to-earth-and-makes-precision-autopilot-landing/ [retrieved 21 June 2017]

${ }^{32}$ Virgin Spaceship

${ }^{33} \mathrm{https} / / /$ www.wired.com/2009/12/spaceshiptwo-christened-as-vss-enterprise/ [retrieved 21 June 2017]

${ }^{34}$ Virgin Mothership

${ }^{35} \mathrm{http}: / /$ thespaceshipcompany.com [retrieved 21 June 2017]

${ }^{36} \mathrm{https} / / / \mathrm{www} . n t s b . g o v /$ investigations/AccidentReports/Pages/AAR1502.aspx [retrieved 22 June 2017]

$37 \mathrm{http}: / / \mathrm{www}$.virgingalactic.com/press/sir-richard-branson-unveils-virgin-galactics-new-spaceship-named-vss-unity -by-professor-stephen-hawking/ [retrieved 21 June 2017] 
Enterprise to break apart in flight. The Unity flight-test program began on September 8, 2016, and is still underway. ${ }^{38}$

Sir Richard had been enamored with spaceflight since the time he sat in his parents' living room and watched Neil and Buzz walk on the moon. ${ }^{39}$ Perhaps the motivation for the development of his suborbital rocket for tourists is best summarized on the Virgin Galactic "Why we go" web page: "People all around the world have experienced a sense of awe as they look up at the night sky. We discover a limitless universe of wonder," and therefore, there is much utility in sending satellites to space, "but satellites are not sufficient: we as a species also dare to push new boundaries. Perhaps it is in our culture, perhaps it is in our DNA, or perhaps it is a bit of each, but humans seem hardwired to explore." 40

\section{LauncherOne}

For Virgin Galactic, "Satellites may not be sufficient ..." to scratch the itch of the desire of humans to explore, but launching satellites into space may potentially be a lucrative business. In July 2012, Virgin Galactic announced that it was developing the LauncherOne launch vehicle to deliver small satellites to orbit.

LauncherOne was originally targeted to carry a 225-kilogram payload to low Earth orbit and was intended to be air-launched from the WhiteKnightTwo mothership. ${ }^{41}$ As the development of LauncherOne progressed, Virgin Galactic doubled the payload capability to 400 kilograms. The LauncherOne Newton engine was apparently capable of propelling a larger launch vehicle than WhiteKnightTwo was capable of carrying. To accommodate a larger, more capable LauncherOne, Virgin Galactic announced on December 3, 2015, that it would use a modified Boeing 747 instead of WhiteKnightTwo as the mothership. The new mothership of the company is Cosmic Girl, acquired from the Virgin Atlantic airline fleet. Cosmic Girl is being modified to carry LauncherOne under its port-side wing. ${ }^{42}$

On March 2, 2017, Branson and Virgin Galactic announced a new Virgin-branded company, Virgin Orbit, that would be responsible for small satellite launch services, including services provided by LauncherOne. ${ }^{43}$ The company's motivation behind developing Virgin Orbit is “... to open space to many more missions by dramatically decreasing the price of flights." ${ }^{\prime 4}$ Air-launch is a means to that end, but the company has another benefit in mind by utilizing air-launch, flexibility. This benefit is succinctly stated on the company website:

Starting each mission with an airplane rather than a traditional groundbased [sic] launch pad offers performance benefits in terms of payload capacity, but more importantly, air-launch offers an unparalleled level of flexibility. ... LauncherOne will operate from a variety of locations independently of traditional launch ranges - which are often congested with traffic - and will have the ability to operate through or around weather conditions and other impediments that delay traditional launches. ${ }^{45}$

\section{Stratolaunch}

In addition to the investment made in SpaceShipOne, Paul Allen has invested in another space launch project, Stratolaunch. According to the Stratolaunch website, "Stratolaunch is the world's largest aircraft by wingspan and is the largest all-composite [air]plane ever built." Stratolaunch is intended to air-launch very large rockets on the order of 500,000 lb, and with "an operational range of approximately 2,000 nautical miles, ... is capable of delivering payloads to multiple orbits and inclinations in a single mission."

For this development, Allen is once again teamed with Scaled Composites who are building the airplane under contract to Allen's company Vulcan, Inc. (Seattle, Washington).

What motivates Allen to undertake such a grand development? He wants to reduce the cost of access to lowEarth orbit. And for Allen, it is personal. In his words:

Like millions of others, I was enthralled by the idea of space exploration, and have been ever since. But I would never have imagined that, more than 50 years [after Russian Cosmonaut Yuri Gagarin became the first man in space], access to

\footnotetext{
${ }^{38} \mathrm{http}: / /$ spacenews.com/second-spaceshiptwo-completes-first-test-flight/ [retrieved 21 June 2017]

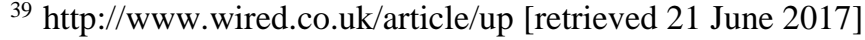

${ }^{40} \mathrm{http}: / /$ www.virgingalactic.com/why-we-go/ [retrieved 21 June 2017]

${ }^{41} \mathrm{http}: / /$ spacenews.com/virgin-galactic-developing-small-satellite-launcher/ [retrieved 23 June 2017]

${ }^{42} \mathrm{http}: / /$ spacenews.com/virgin-galactic-acquires-boeing-747-for-launcherone-missions/ [retrieved 23 June 2017]

${ }^{43} \mathrm{http}: / / \mathrm{www}$.virgingalactic.com/press/virgin-galactic-announces-new-commercial-space-company-virginorbitfeaturing-launcherone-small-satellite-launch-service-dan-hart-former-boeing-executive-appointed-president-ofvirgin-orbit/ [retrieved 23 June 2017]

${ }^{44}$ https://www.virgin.com/richard-branson/introducing-virgin-orbit-brand [retrieved 23 June 2017]

${ }^{45}$ https://virginorbit.com [retrieved 23 June 2017]
} 
low Earth orbit (LEO) would still be costly, complex and difficult. I am determined to change this [situation] to help maximize the potential of space to improve life here on Earth. ${ }^{46}$

Allen's vision of developing Stratolaunch is becoming a reality. The first Stratolaunch vehicle rolled out of her hangar at the Mojave Air and Space Port on May 31, 2017, officially marking the beginning of the ground testing phase of development. ${ }^{47}$ The flight-test program will begin soon. Then the world will find out whether or not the Stratolaunch is the means by which Allen's quest to reduce the cost of space access is realized.

\section{Conclusion}

From the earliest days of manned aviation, air-launch has been considered and utilized. The first application of air-launch was when Montgomery demonstrated flight of his Santa Clara glider just 2 years after the Wright's flight at Kitty Hawk. Since that time, air-launch has been utilized to great advantage in flight of both heavier-than-air and lighter-than-air vehicles. Air-launch has been utilized for: lifting early gliders, demonstrating the aero-tow technique, augmenting air-forces to move materiel and troops and to deliver munitions, extending flight distances for commercial transport, researching advanced aerodynamics and systems, enabling new military missions, and for launching satellites and satellite killers into space. Air-launch is also envisioned as a means of enabling future services, such as: delivering consumer goods to neighborhoods, sending tourists above the Karmann line, and delivering satellites into orbit.

Across the several applications identified in this paper, the motivations to use air-launch have varied. In every case, however, use of air-launch was motivated by an advantage gained through multiple air-vehicles joined and working together, rather than each air-vehicle working independently. These advantages can be summarized as: aero-performance gains, simplified systems, increased tactical advantage, or increased mission flexibility.

\section{Acknowledgments}

The authors thank Karl Bender, Kaylynn Clark, and Renee Marchiano of the AFRC Research Library who provided the many books (including from their personal libraries) required to write this paper and who tracked down several obscure articles. The authors would also like to thank D. Chris Cottrill of the Smithsonian Libraries, National Air \& Space Museum, who graciously provided the Chanute-Mouillard letters.

\section{References}

[1] Chanute, O., and Mouillard, L-P., “The Chanute-Mouillard Correspondence: April 16, 1890 to May 20, 1897," reproduced from the National Air and Space Museum Library Special Collections, Smithsonian Institution, Washington, D.C., p. 108.

[2] The American Society of Mechanical Engineers, John Joseph Montgomery 1883 Glider, New York, May 11, 1996 , p. 5.

[3] Montgomery, J., "Some Early Gliding Experiments in America," Aeronautics, Vol. 4, No. 1, Jan. 1909, p. 50.

[4] Robinson, D. H., The Zeppelin in Combat, $3^{\text {rd }}$ ed., John W. Caler Publications Corporation, Sun Valley, California, 1971, pp. 234-247.

[5] Guttman, J., Sopwith Camel, Kindle ed., Osprey Publishing Ltd., Oxford, United Kingdom, 2012, loc. 646.

[6] Smith, R. K., The Airships Akron \& Macon: Flying Aircraft Carriers of the United States Navy, United States Naval Institute, Annapolis, Maryland, 1965.

[7] Shock, J. R., U.S. Army Airships 1908-1942, $1^{\text {st }}$ ed., Atlantis Productions, Edgewater, Florida, 2002.

[8] Short, S., "In the Wake of the Albatross and Seagull, a Look Back to 1922," American Aviation Historical Society Journal, Vol. 62, No. 1, 2017.

[9] Curtiss, G. H., "In the Wake of the Albatross," New York Tribune, Aug. 23, 1922, p. 10.

[10] Hirschel, E. H, Prem, H., and Madelung, G., Aeronautical Research in Germany - from Lilienthal until Today, Springer, Bonn, Germany, 2004, p. 204.

[11] Mrazek, J. E., Airborne Combat: The Glider War/Fighting Gliders of World War II, Kindle ed., Stackpole Books, Mechanicsburg, Pennsylvania, 2011.

[12] Green, W., Warplanes of the Third Reich, Galahad Books, New York, 1990, pp. 594-605.

[13] Newcome, L. R., "The Concept Takes Flight," Unmanned Aviation: A Brief History of Unmanned Aerial Vehicles, $1^{\text {st }}$ ed., American Institute of Aeronautics and Astronautics, Reston, Virginia, 2004, pp. 18-21.

[14] Axelrod, A., Kingston, J., "V-1 buzz bomb," Encyclopedia of World War II, Vol. 1, 1' ed., Facts on File, New York, 2007, p. 856.

[15] Simons, G. M., Operation LUSTY: The Race for Hitler's Secret Technology, $1^{\text {st }}$ ed., Pen and Sword Aviation, South Yorkshire, United Kingdom, 2016, pp. 51-59.

${ }^{46} \mathrm{https}: / /$ www.linkedin.com/pulse/tackling-space-challenge-paul-g-allen [retrieved 21 June 2017]

${ }^{47} \mathrm{http}: / /$ spacenews.com/stratolaunch-rolls-out-giant-aircraft/ [retrieved 21 June 2017] 
[16] Bishop, C., "Air-to-Ground Weapons," The Encyclopedia of Weapons of World War II, 2 ${ }^{\text {nd }}$ ed., Barnes and Noble Books, New York, 1998, pp. 416-417.

[17] Mindling, G., and Bolton, R., "Playing Catch-up," U.S. Air Force Tactical Missiles, $2^{\text {nd }}$ ed., Lulu.com Publishing, Morrisville, North Carolina, 2011, pp. 29-36.

[18] Lepage, J-D. C. G., "Mistel Composite," Aircraft of the Luftwaffe, 1935-1945: An Illustrated Guide, $1^{\text {st }}$ ed., McFarland \& Company, Inc., Publishers, Jefferson, North Carolina, 2009, pp. 159-161.

[19] Friedman, N., "Notes," Naval Anti-Aircraft Guns and Gunnery, 1st ed., Seaforth Publishing, South Yorkshire, United Kingdom, 2013, p. 324.

[20] Barlow, H., "The Divine Wind," Dead for Good: Martyrdom and the Rise of the Suicide Bomber, 2 ${ }^{\text {nd }}$ ed., Routledge, New York, 2016, p. 109.

[21] Neufeld, J., "Early Experimental Guided Missiles," The development of ballistic missiles in the United States Air Force 1945-1960, 1st ed., United States Air Force Historical Studies Office, Washington, D.C., 1990, pp.10-11.

[22] Polmar, N., and Allen, T. B., "Bat Missile," World War II: The Encyclopedia of the War Years, 1941-1945, 2" ed., Dover Publications, Mineola, New York, 2012, p. 136.

[23] Tucker, S. C., "Glide Bombs," World War II at Sea: An Encyclopedia, Vol. 1, $1^{\text {st }}$ ed., ABC-CLIO, LLC, Santa Barbara, California, 2012, p. 311.

[24] Tucker, S. C., “Azon Smart Bomb," Almanac of American Military History, Vol. 1, $1^{\text {st }}$ ed., ABC-CLIO, LLC, Santa Barbara, California, 2013, pp. 1636.

[25] Angelucci, E., World Encyclopedia of Civil Aircraft, Willow Books, London, 1984, p. 251.

[26] Jackson, A. J., British Civil Aircraft since 1919, Vol. 3, $2^{\text {nd }}$ ed., 1974, p. 302.

[27] Yeager, C., and Janos, L., Yeager: An Autobiography, Bantam Books, New York, 1985.

[28] National Aeronautics and Space Administration, "NASA Armstrong Fact Sheet: First Generation X-1," https://www.nasa.gov/centers/armstrong/news/FactSheets/FS-085-DFRC.html [retrieved 31 July 2017].

[29] National Aeronautics and Space Administration, "NASA Armstrong Fact Sheet: D-558-II Skyrocket," https://www.nasa.gov/centers/armstrong/news/FactSheets/FS-035-DFRC.html [retrieved 31 July 2017].

[30] National Aeronautics and Space Administration, "NASA Armstrong Fact Sheet: Bell X-2 Starbuster," https://www.nasa.gov/centers/armstrong/news/FactSheets/FS-079-DFRC.html [retrieved 31 July 2017].

[31] Hallion, R. P., and Gorn, M. H., On the Frontier: Experimental Flight at NASA Dryden, Smithsonian Books, Washington, DC, 2010.

[32] Pace, S., "The 1950s: Forthcoming Technologies," The Projects of Skunk Works: 75 Years of Lockheed Martin's Advanced Development Programs, $1^{\text {st }}$ ed., Voyageur Press, Minneapolis, Minnesota, 2016, p. 56.

[33] Jenkins, D. R., "Prototypes," X-Planes Photo Scrapbook, $1^{\text {st }}$ ed., Specialty Press, North Branch, Minnesota, 2004, p. 119.

[34] National Aeronautics and Space Administration, "NASA Armstrong Fact Sheet: X-15 Hypersonic Research Program," https://www.nasa.gov/centers/armstrong/news/FactSheets/FS-052-DFRC.html [retrieved 31 July 2017].

[35] National Aeronautics and Space Administration, "NASA Armstrong Fact Sheet: Lifting Bodies," https://www.nasa.gov/centers/armstrong/news/FactSheets/FS-011-DFRC.html [retrieved 31 July 2017].

[36] Landis, T. R., "M-21 and D-21 Tagboard and Senior Bowl," Lockheed Blackbird Family: A-12, YF-12, D-21/M-21 \& SR-71 Photo Scrapbook, $1^{\text {st }}$ ed., Specialty Press, North Branch, Minnesota, 2010, pp. 36-51.

[37] National Aeronautics and Space Administration, "NASA Armstrong Fact Sheet: Highly Maneuverable Aircraft Technology," https://www.nasa.gov/centers/armstrong/news/FactSheets/FS-025-DFRC.html [retrieved 31 July 2017].

[38] National Aeronautics and Space Administration, "NASA Armstrong Fact Sheet: Hyper-X Program" https://www.nasa.gov/centers/armstrong/news/FactSheets/FS-040-DFRC.html [retrieved 31 July 2017].

[39] United States Air Force, "X-51A Waverider," http://www.af.mil/About-Us/Fact-Sheets/Display/Article/104467/x-51awaverider/ [retrieved 1 August 2017].

[40] Wade, A., "September 1946: the Miles 52, the supersonic aircraft that never was," https://www.theengineer.co.uk/september-1946-the-miles-52-the-supersonic-aircraft-that-never-was/ [retrieved 1 August 2017].

[41] Flanagan, W. A., "Piloted Transonic Research Aircraft: The Early Days," Aviation Records in the Jet Age: The Planes and Technologies Behind the Breakthroughs, $1^{\text {st }}$ ed., Specialty Press, Forest Lake, Minnesota, 2017, pp. 64-65.

[42] Michel, M., "A French revolution," http://www.kaiserslauternamerican.com/a-french-revolution/ [retrieved 1 August 2017].

[43] Gordon, Y., and Gunston, B., Soviet X-Planes, $1^{\text {st }}$ ed., Midland Publishing, Leicester, United Kingdom, 2000, pp. 120, 216217.

[44] van Pelt, M., "Breaking the Barrier," Rocketing Into the Future: The History and Technology of Rocket Planes, $1^{\text {st }}$ ed., Springer, New York, 2012, p. 226.

[45] Gunston, B., “Tsybin,” The Encyclopedia of Russian Aicraft: 1875-1995, Motorbooks International, Osceola, Wisconsin, 1995, pp. 376-377.

[46] National Aeronautics and Space Administration, "Space Shuttle Approach and Landing Tests (ALT)," https://www.nasa.gov/centers/dryden/multimedia/imagegallery/ALT/ALT_proj_desc.html [retrieved 1 August 2017].

[47] National Aeronautics and Space Administration, "NASA Armstrong Fact Sheet: X-38 Prototype Crew Return Vehicle," https://www.nasa.gov/centers/armstrong/news/FactSheets/FS-038-DFRC.html [retrieved 1 August 2017].

[48] National Aeronautics and Space Administration, "NASA Dryden Past Projects: X-40A Space Maneuver Vehicle," https://www.nasa.gov/centers/dryden/history/pastprojects/X40A/index.html [retrieved 1 August 2017]. 
[49] United States Air Force, "X-37B Orbital Test Vehicle," http://www.af.mil/About-Us/Fact-Sheets/Display/Article/104539/x37b-orbital-test-vehicle/ [retrieved 1 August 2017].

[50] United States Air Force, "X-37B Orbital Test Vehicle-4 lands at Kennedy Space Center," http://www.af.mil/News/ArticleDisplay/Article/1175402/x-37b-orbital-test-vehicle-4-lands-at-kennedy-space-center/ [retrieved 1 August 2017].

[51] Clark, S., "Sierra Nevada to resume Dream Chaser flight tests," Spaceflight Now, https://spaceflightnow.com/2017/03/06/sierra-nevada-to-resume-dream-chaser-flight-tests/ [retrieved 1, August 2017].

[52] van den Abeelen, L., Spaceplane HERMES: Europe's Dream of Independent Manned Spaceflight, $1^{\text {st }}$ ed., Springer Praxis Books, Cham, Switzerland, 2017, pp. 386-389.

[53] Anderson, C. E., "Aircraft Wingtip Coupling Experiments," Fifty-Fourth Symposium Proceedings of the Society of Experimental Test Pilots, Lancaster, California, 2010, pp. 225-242.

[54] Jenkins, D. R., Magnesium Overcast: The Story of the Convair B-36, Specialty Press, North Branch, Minnesota, 2002.

[55] Bille, M., and Lishock, E., "NOTSNIK: The Secret Satellite," AIAA-2002-0314, 2002.

[56] Scala, K. J., "Rockets Red Glare," Quest, Vol. 3, No. 1, Spring 1994, pp. 58-61.

[57] Horton, V. W., and Messing, W. E., "Some Operational Aspects of Using a High-Performance Airplane as a First-Stage Booster for Air-Launching Solid-Fuel Sounding Rockets," NASA TN-1279, 1963.

[58] Schade, C., and Mosier, M., "The Pegasus Launch Vehicle New Capabilities and the Future," AIAA 94-1172, 1994.

[59] Mosier, M. R., and Steffy, D. A., "Pegasus: Key to Low-Cost Space Applications," Space Commercialization: Launch Vehicles and Programs, Progress in Astronautics and Aeronautics, AIAA, Washington, D.C., 1990, pp. $72-89$.

[60] Tucker, T., "The Eclipse Project,” NASA SP-2000-4523, 2000.

[61] Seedhouse, E., Virgin Galactic: The First Ten Years, Kindle ed., Springer-Praxis Books, Chichester, United Kingdom, 2015. 